\title{
Non-Exosomal and Exosomal Circulatory MicroRNAs: Which Are More Valid as Biomarkers?
}

\author{
Nik Nur Syazana Binti Nik Mohamed Kamal and Wan Nazatul Shima Shahidan * \\ Craniofacial Science Laboratory, School of Dental Sciences, Universiti Sains Malaysia, Health Campus, Kubang Kerian, Malaysia
}

\section{OPEN ACCESS}

Edited by:

Syed Nasir Abbas Bukhari,

Al Jouf University,

Saudi Arabia

Reviewed by:

Simona Taverna,

Italian National Research Council

(CNR), Italy

Maria Abdul Ghafoor Raja,

Northern Border University,

Saudi Arabia

*Correspondence: Wan Nazatul Shima Shahidan shima@usm.my

Specialty section: This article was submitted to Experimental Pharmacology and Drug Discovery,

a section of the journal

Frontiers in Pharmacology

Received: 28 July 2019 Accepted: 19 November 2019 Published: 20 January 2020

Citation:

Nik Mohamed Kamal NNSB and Shahidan WNS (2020) Non-Exosomal and Exosomal Circulatory MicroRNAs: Which Are More Valid as Biomarkers?

Front. Pharmacol. 10:1500. doi: 10.3389/fphar.2019.01500
MicroRNAs (miRNAs) are a group of small non-coding RNAs with approximately 19-25 nucleotides that are involved in regulating a range of developmental and physiological processes. Non-exosomal circulating and exosomal miRNAs have also been proposed to be useful in diagnostics as biomarkers for diseases and different types of cancer. In this review, the quantity of miRNAs and of reliable experimental data analyses of miRNAs that come from exosomal and non-exosomal sources are discussed from the perspective of their use as biomarkers for cancer and other diseases, including viral infections, nervous system disorders, cardiovascular disorders, and diabetes. We summarize other research findings regarding the use of miRNA from these two sources as biomarkers in diagnostics and clinical use. The challenges in using miRNA from these two sources in cancer and disease diagnostics are evaluated and discussed. Validation of specific miRNA signatures as biomarkers is a critical milestone in diagnostics.

\section{Keywords: exosome, miRNA, biomarker, body fluid, non-exosomal}

\section{METHODOLOGY AND DELIMITATION}

A PubMed database search on $4^{\text {th }}$ April 2018 with the keywords "miRNA AND circulating" resulted in a total of 3558 articles. When the parameter "full-text" was applied, 3510 articles remained. After a second parameter, "free full-text," was applied, a total of 2055 articles were left. These articles were then manually classified into a group of original articles and a group of "others" (not related to the topic, reviews, reports, editorials, commentaries, etc.) Here we are focusing on original articles considering exosomal and non-exosomal circulatory miRNAs as potential biomarkers. A total of 69 original articles were found to be related to the topic.

Among the selected original articles, only six reported on non-exosomal circulating miRNAs: four studied microparticle (MP)-associated miRNAs, and two studied high-density lipoprotein (HDL)-associated miRNAs (Figure 1; Table 1). Meanwhile, a total of 31 of the original articles selected were exosomal miRNA studies: 15 used only plasma, 13 used only serum, 1 used both urine and plasma, 1 used plasma and serum, and 1 used only unstimulated whole saliva as the source of miRNAs for their study (Figure 1; Table 2). On the other hand, 32 of the original articles selected formed a group that were both exosomal and non-exosomal studies: 9 used only plasma, 14 used only serum, 1 used serum and saliva, 1 used vitreous humor and serum, 1 used whole blood and serum, 2 used plasma and conditioned media, and 4 used serum and conditioned media as the source of circulating miRNAs (Figure 1; Tables 3 and $\mathbf{4}$ ). 


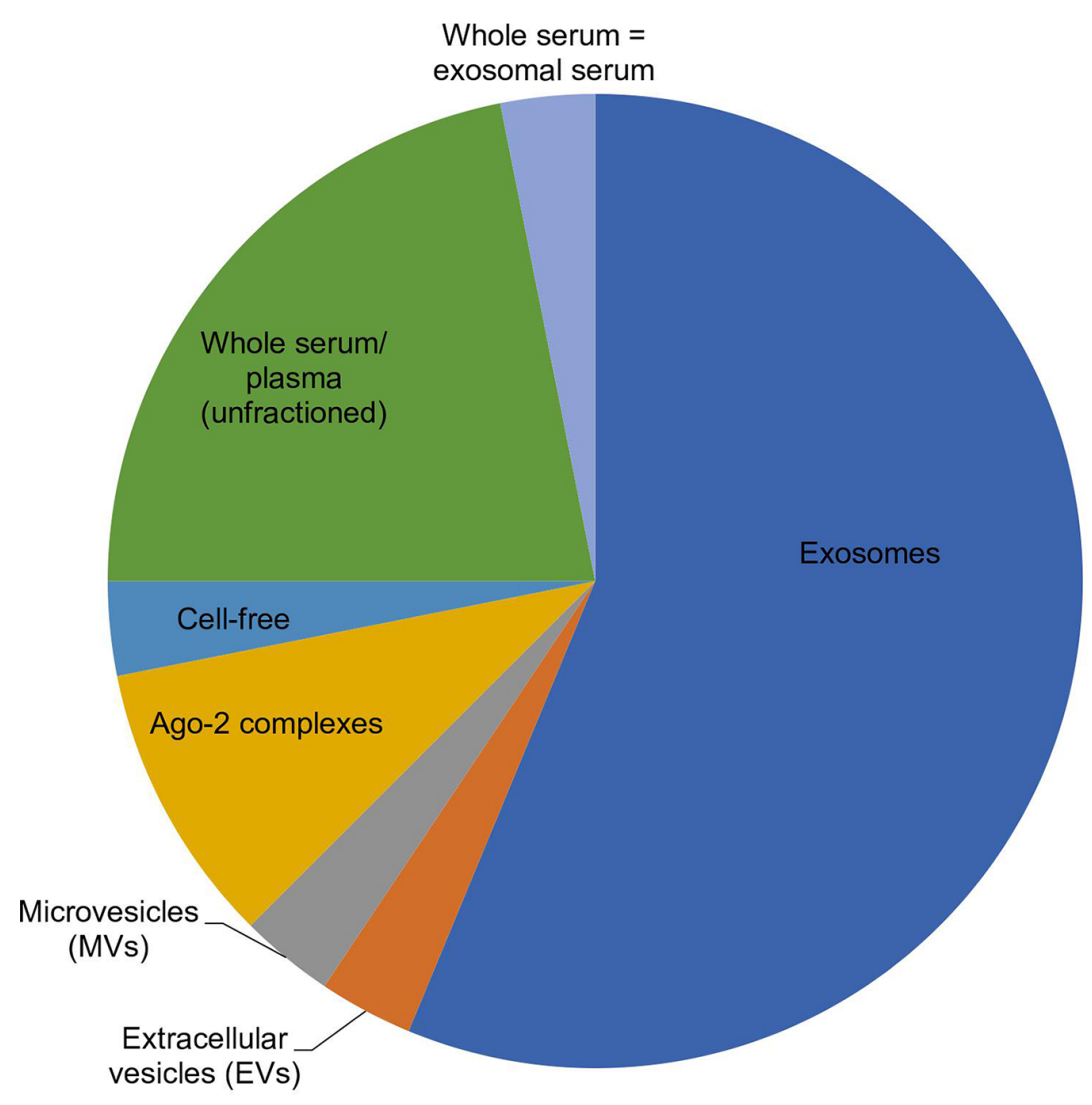

FIGURE 1 | Pie chart showing the distribution of 32 selected articles in which a miRNA origin was preferred, according to their comparative study findings. Out of 32 articles, 18 chose exosomes, 1 chose EVs, 1 chose MVs, 3 chose Ago-2 complexes, 1 chose cell-free, 7 chose unfractioned, and 1 showed similar expression between whole serum versus exosomes, as the best origin for miRNAs used in biomarker studies.

\begin{abstract}
Abbreviations: ACA, adrenocortical adenomas; ACC, adrenocortical cancer; Ago, Argonaute; ALP, alkaline phosphate; AMI, acute myocardial infarction; ART, anti-retroviral therapies; AUC, area under the curve; CA, cancer antigen; CAD, coronary artery disease; CEA, carcinoembryonic antigen; CRC, colorectal cancer; CRPC, castration-resistant prostate cancer; CT, computed tomography; CTnI, cardiac troponin I; ESCC, esophageal squamous cell carcinoma; EMP, endothelial microparticle; FSGS, focal segmental glomerulosclerosis; HDL, high-density lipoprotein; HCC, hepatocellular carcinoma; HF, heart failure; HP, high protein; hsa, "homo sapiens" = human microRNA prefix; IH, intermittent hypoxia; let, microRNA prefix that is conserved in many species; LT, liver transplant; OHRQoL, oral health-related quality of life; OvCa, ovarian cancer; MCD, minimal change disease; miRNA, microRNA; miR, mature form of microRNA, MoCA, Montreal Cognitive Assessment; MP, microparticle; MS, multiple sclerosis; MRI, magnetic resonance imaging; MVB, multivescular bodies; NAFLD, non-alcoholic fatty lipid disease; NPC, nasopharyngeal carcinoma; NSCLC, non-small cell lung cancer; PEG, polyethylene glycol; PET, positron emission tomography; PCa, prostate cancer; qPCR, quantitative polymerase chain reaction; RISC, RNA-induced silencing complex; ROC, receiver operating curve; RNP, ribonucleoprotein; RT-PCR, reverse transcription polymerase chain reaction; RT-qPCR, real-time reverse transcription polymerase chain reaction; SEC, size-exclusion chromatography; SCAD, stable coronary artery disease; SCC, squamous cell cancer; SS, synovial sarcoma; TNM, tumor/nodes/metastasis; UA, unstable vagina; $\mathrm{UC}$, ultracentifugation; $\mathrm{UM}$, uveal meloma; $\mathrm{VH}$, citreous humor; VHR, very high risk.
\end{abstract}

\section{BIOMARKER}

A biomarker is defined as an objectively measured and evaluated indicator of normal biological processes, pathogenic processes, or pharmacological responses to therapeutic intervention. A biomarker can thus provide impartial information regarding the current physiological state of living organisms (Gill et al., 2017). Biomarkers exist in the form of antibodies (Dardari et al., 2000: IgG-ZEBRA as a biomarker in young patients with nasopharyngeal carcinoma), microbes (Shah et al., 2018: the fecal microbiome as a biomarker of colorectal cancer), DNA (Teo et al., 2019: sequencing of circulating cell-free DNA [cfDNA] from human blood plasma as a noninvasive methodology to study age-associated changes in the epigenome in vivo), RNA/miRNA (as tabulated in this review), lipids (Seow et al., 2019: the lipid fraction of the solid nonenhancing region showed potential as a novel prognostic biomarker of survival outcome in glioma), metabolites [Lou et al., 2019: a urinary metabolite of polycyclic aromatic hydrocarbons, 8hydroxy-2'-deoxyguanosine (8-OHdG), can be a biomarker of oxidative stress in pregnant women], and/or protein [Xu et al., 2019: serum protein, the insulin-like growth factor-binding protein 
TABLE 1 | Summary of original articles involving non-exosomal circulating miRNAs as biomarkers.

\begin{tabular}{|c|c|c|c|c|c|c|c|}
\hline Reference & Source of miRNAs & $\begin{array}{l}\text { MP/HDL isolation } \\
\text { method }\end{array}$ & $\begin{array}{l}\text { miRNA isolation } \\
\text { method }\end{array}$ & $\begin{array}{c}\text { miRNA-related } \\
\text { experiment }\end{array}$ & Highlighted miRNAs & Potential biomarker & Other information \\
\hline $\begin{array}{l}\text { Giannella et al., } \\
2017\end{array}$ & $\begin{array}{l}\text { Endothelial } \\
\text { microparticles } \\
\text { (EMPs) - platelet- } \\
\text { poor plasma }\end{array}$ & $\begin{array}{l}\text { Centrifugation at } \\
18,000 \mathrm{~g}\end{array}$ & $\begin{array}{l}\text { RNeasy MinElute } \\
\text { Cleanup kit }\end{array}$ & RT-qPCR & miR126-3p & $\begin{array}{l}\text { Vascular endothelial repair in } \\
\text { different glucose tolerance }\end{array}$ & $\begin{array}{l}\text { Downregulation in hyperglycemic condition } \\
\text { resembling vascular protection of miR-126- } \\
3 p \text { is lost in early phases of glucose } \\
\text { intolerance }\end{array}$ \\
\hline Zhang et al., 2017 & EMPs - plasma & $\begin{array}{l}\text { Centrifugation at } \\
13,000 \mathrm{~g}\end{array}$ & NA & RT-qPCR & miR-92a & $\begin{array}{l}\text { Early detection of acute } \\
\text { myocardial infarction (AMI); } \\
\text { differentiation from stable } \\
\text { coronary artery disease (SCAD) }\end{array}$ & $\begin{array}{l}\text { 1. Upregulation pattern: } \\
\text { AMl > SCAD > control } \\
\text { 2. miRNA expression parallel with increase in } \\
\text { CD } 31^{+} / C D 42 b^{-} \text {MPs } \\
\text { 3. AUC of EMPs, miR-92a, and cTnl were } \\
\text { 8.925, } 8.883 \text {, and } 9.123 \text {, respectively, } \\
\text { suggesting combination usage for a more } \\
\text { specific and sensitive biomarker }\end{array}$ \\
\hline Jansen et al., 2016 & $\begin{array}{l}\text { MP-containing and } \\
\text { cell-free plasma }\end{array}$ & $\begin{array}{l}\text { Centrifugation at } \\
13,000 \mathrm{~g}\end{array}$ & $\begin{array}{l}\text { TRlzol-based miR } \\
\text { isolation }\end{array}$ & RT-qPCR & miR-126 and miR-26 & SCAD & $\begin{array}{l}\text { 1. Downregulation of miRNAs in diabetic vs. } \\
\text { non-diabetic patients } \\
\text { 2. Downregulation leads to high risk of } \\
\text { coronary artery disease (CAD) } \\
\text { 3. MP plasma miRNAs were better than cell- } \\
\text { free miRNAs in predicting cardiovascular } \\
\text { events in SCAD patients }\end{array}$ \\
\hline $\begin{array}{l}\text { Niculescu et al., } \\
2015\end{array}$ & $\begin{array}{l}\mathrm{HDL} \text { - serum } \\
\mathrm{HDL}_{2} \text { - serum } \\
\mathrm{HDL}_{3} \text { - serum }\end{array}$ & $\begin{array}{l}\text { Isopycnic density } \\
\text { gradient UC }\end{array}$ & $\begin{array}{l}\text { miRNeasy serum/ } \\
\text { plasma kit }^{\dagger}\end{array}$ & $\begin{array}{l}\text { 1. Pathway-focused } \\
\text { Human CVD miScript } \\
\text { miRNA PCR array }{ }^{\dagger} \\
\text { 2. RT-qPCR }\end{array}$ & $\begin{array}{l}\text { miR-486 and miR-92 } \\
\text { miR-486 } \\
\text { miR-92 }\end{array}$ & Vulnerable CAD & $\begin{array}{l}\text { Upregulation in vulnerable CAD vs. stable } \\
\text { CAD } \\
\text { Upregulation in both unstable vagina (UA) } \\
\text { and myocardial infarction (MI) patients; can } \\
\text { differentiate between CAD and stable CAD }\end{array}$ \\
\hline Diehl et al., 2012 & MPs - platelet & $\begin{array}{l}\text { Centrifugation at } \\
16,000 \mathrm{~g}\end{array}$ & Trizol & $\begin{array}{l}\text { 1. RT-qPCR } \\
\text { 2. Next-generation } \\
\text { sequencing }^{\mathrm{c}}\end{array}$ & $\begin{array}{l}\text { miR-19, miR-21, miR- } \\
\text { 132, miR-133, miR- } \\
\text { 146, miR-155, miR- } \\
\text { 223, miR-377, miR- } \\
\text { 451, miR-641, miR- } \\
\text { 887, miR-1246, and } \\
\text { miR-4284 }\end{array}$ & CAD & $\begin{array}{l}\text { miRNAs were associated with MP-containing } \\
\text { plasma compared to MP-free plasma of } \\
\text { CAD patients }\end{array}$ \\
\hline Tabet et al., 2016 & HDL - serum & PEG-6000 method & $\begin{array}{l}\text { Qiazol miRNA-easy } \\
\text { kits }^{f}\end{array}$ & RT-qPCR & $\begin{array}{l}\text { miR-223 } \\
\text { miR-16 and Mir-122 }\end{array}$ & Weight loss & $\begin{array}{l}\text { Downregulation in HP patient vs. normal } \\
\text { protein diet } \\
\text { According to previous study: downregulation } \\
\text { in gastric bypass bariatric surgery patients }\end{array}$ \\
\hline
\end{tabular}

IIllumina; ${ }^{\text {QQiagen. }}$

AMI, acute myocardial infarction; AUC, area under the curve; CAD, coronary artery disease; EMP, endothelial microparticle; HDL, high-density lipoprotein; HP, high protein; hsa, "homo sapiens" = human microRNA prefix; let, microRNA prefix that is conserved in many species; miRNA, microRNA; miR, mature form of microRNA, NA, not available; PEG, polyethylene glycol; RT-qPCR, real-time reverse transcription polymerase chain reaction; SCAD, stable coronary artery disease;

UA, unstable vagina; UC, ultracentifugation. 


\begin{tabular}{|c|c|c|c|c|c|c|c|}
\hline Reference & Source & $\begin{array}{l}\text { Exosome isola- } \\
\text { tion method }\end{array}$ & $\begin{array}{l}\text { miRNA isolation } \\
\text { method }\end{array}$ & $\begin{array}{l}\text { miRNA-related } \\
\text { experiment }\end{array}$ & Highlighted miRNAs & Potential biomarker & Other information \\
\hline Fu et al., 2018 & Serum & $\begin{array}{l}\text { qEV size exclusion } \\
\text { columns }^{\mathrm{a}}\end{array}$ & $\begin{array}{l}\text { HiPure liquid RNA } \\
\text { miRNA kit }\end{array}$ & $\begin{array}{l}\text { 1. Small RNA } \\
\text { sequencing } \\
\text { 2. Stem-loop RT- } \\
\text { gPCR }\end{array}$ & miR-17-5p and miR-92a-3p & $\begin{array}{l}\text { Primary vs. metastatic } \\
\text { colorectal cancer (CRC) }\end{array}$ & $\begin{array}{l}\text { Upregulation of miRNAs is associated with } \\
\text { pathologic stages and grades of CRC }\end{array}$ \\
\hline Li et al., 2017 & Plasma & $\begin{array}{l}\text { ExoCap exosome } \\
\text { isolation and } \\
\text { enrichment kit }\end{array}$ & NA & RT-qPCR & $m i R-96-5 p$ and miR-149 & Stage III CRC & \\
\hline Yan et al., 2017 & Serum & $\begin{array}{l}\text { Total exosome } \\
\text { isolation } \mathrm{kit}^{\mathrm{e}}\end{array}$ & $\begin{array}{l}\text { Trizol LS of } \\
\text { miRNeasy mini kit }\end{array}$ & $\begin{array}{l}\text { 1. Microarray } \\
\text { 2. RT-qPCR }\end{array}$ & $\begin{array}{l}\text { miR-638 } \\
\text { miR-548c-5p, miR-638, miR- } \\
\text { 5787, miR-8975, and miR- } \\
\text { 6869-5p }\end{array}$ & $\mathrm{CRC}$ & $\begin{array}{l}\text { Downregulation of miRNA associated with } \\
\text { increase in liver metastasis and later tumor/ } \\
\text { nodes/metastasis (TNM) stage of CRC } \\
\text { Involved in the process of glucose metabolism } \\
\text { in CRC }\end{array}$ \\
\hline $\begin{array}{l}\text { Ostenfeld et al., } \\
2016\end{array}$ & $\begin{array}{l}\text { Pooled serum; } \\
\text { pooled plasma }\end{array}$ & $\begin{array}{l}\text { Ultracentrifugation } \\
\text { (UC) }\end{array}$ & miRNeasy mini kit ${ }^{f}$ & $\begin{array}{l}\text { miRCURY LNATM } \\
\text { universal RT } \\
\text { microRNA PCR } \\
\text { analysis }\end{array}$ & $\begin{array}{l}\text { miR-16-5p, miR-23a-3p, } \\
\text { miR-23b-3p, miR-27a-3p, } \\
\text { miR-27b-3p, miR-30b-5p, } \\
\text { miR-30c-5p, and miR-222-3p }\end{array}$ & $\mathrm{CRC}$ & miRNAs were tumor originated \\
\hline $\begin{array}{l}\text { Ogata-Kawata } \\
\text { et al., } 2014\end{array}$ & $750 \mu \mathrm{l} \mathrm{serum}$ & UC & $\begin{array}{l}\text { Trizol-LS reagent }+ \\
\text { RNeasy mini spin } \\
\text { columns }^{f}\end{array}$ & $\begin{array}{l}\text { 1. Microarray } \\
\text { 2. RT-qPCR }\end{array}$ & $\begin{array}{l}\text { miR-23a } \\
\text { miR-1246 }\end{array}$ & Early-stage CRC & $\begin{array}{l}95 \% \text { sensitivity for stage } 1 \\
90 \% \text { sensitivity for stage } 1\end{array}$ \\
\hline $\begin{array}{l}\text { Wang et al., } \\
2017\end{array}$ & Plasma & ExoQuick' & miRNeasy micro kit ${ }^{f}$ & RT-qPCR & $m i R-125 a-3 p$ & Colon cancer & $\begin{array}{l}\text { 1. Upregulation in patients with early-stage } \\
\text { colon cancer } \\
\text { 2. miRNA AUC = } 68.55 \% \text {; existing marker- } \\
\text { CEA AUC = 83.6\%; } \\
\text { combination miR-125a-3p and } \\
\text { carcinoembryonic antigen (CEA) AUC }=85.5 \% \\
\text { 3. miR-125a-3p = significant correlation with } \\
\text { only nerve infiltration ( } P<0.01) \text {, but CEA level } \\
\text { correlated with tumor size, infiltration depth, } \\
\text { and differentiation degree }(P<0.05, r= \\
0.3009-0.7270)\end{array}$ \\
\hline $\begin{array}{l}\text { Teng et al., } \\
2017\end{array}$ & Serum & $\begin{array}{l}\text { ExoRNeasy serum/ } \\
\text { plasma midi kit }^{\dagger}\end{array}$ & miRNeasy mini kit ${ }^{f}$ & qPCR & mir-193a & $\begin{array}{l}\text { Tumor progression of colon } \\
\text { cancer }\end{array}$ & $\begin{array}{l}\text { Upregulation of miRNA shown in human colon } \\
\text { cancer patients with more advanced disease }\end{array}$ \\
\hline $\begin{array}{l}\text { Kimura et al., } \\
2018\end{array}$ & Plasma & PEG system & $\begin{array}{l}\text { Plasma/ } \\
\text { Serum Circulating } \\
\text { and Exosomal RNA } \\
\text { Purification kit }\end{array}$ & Real-time PCR & let-7i & Multiple sclerosis (MS) & $\begin{array}{l}\text { Regulates MS pathogenesis by blocking the } \\
\text { IGF1R/TGFBR1 pathway }\end{array}$ \\
\hline $\begin{array}{l}\text { Ebrahimkhani } \\
\text { et al., } 2017\end{array}$ & $1000 \mu \mathrm{l} \mathrm{serum}$ & $\begin{array}{l}\text { RNase } \\
+ \\
\text { SEC }\left(\operatorname{Qev}^{\mathrm{a}}\right)\end{array}$ & $\begin{array}{l}\text { Plasma/ } \\
\text { Serum Circulating } \\
\text { and Exosomal RNA } \\
\text { Purification Mini kit }\end{array}$ & $\begin{array}{l}\text { Small RNA } \\
\text { sequencing }^{\mathrm{C}}\end{array}$ & $\begin{array}{l}\text { miR-15b-5p, miR-23a-3p, } \\
\text { miR-30b,-5p, miR-223-3p, } \\
\text { miR-342-3p, miR-374-5p, } \\
\text { miR-432-5p miR-433-3p, and } \\
\text { miR-485-3p }\end{array}$ & $\begin{array}{l}\text { Relapsing-remitting MS vs. } \\
\text { progressive MS }\end{array}$ & \\
\hline $\begin{array}{l}\text { Rani et al., } \\
2017\end{array}$ & Plasma & $\begin{array}{l}\text { ExoEasy Maxi and } \\
\text { exoRNeasy kit }\end{array}$ & $\begin{array}{l}\text { ExoRNeasy serum/ } \\
\text { plasma maxi kit }^{\dagger}\end{array}$ & $\begin{array}{l}\text { Small RNA } \\
\text { sequencing }\end{array}$ & $\begin{array}{l}\text { miR-10a-5p, miR-10b-5p, } \\
\text { miR-23b-3p, miR-26b-5p, } \\
\text { miR-30c-5p, miR-99a-5p, } \\
\text { miR-125a-5p, miR-125b-5p, } \\
\text { miR-140-3p, miR-186-5p, }\end{array}$ & $\begin{array}{l}\text { Cognitive decline in normal } \\
\text { aging/presymptomic stage of } \\
\text { disease }\end{array}$ & $\begin{array}{l}\text { Monteral Cognitive Assessment (MoCA) scores } \\
\text { were negatively correlated with } 13 \text { miRNAs, } \\
\text { but the miRNA profile was different to previous } \\
\text { reported in Alzheimer's disease }\end{array}$ \\
\hline
\end{tabular}




\begin{tabular}{|c|c|c|c|c|c|c|c|}
\hline Reference & Source & $\begin{array}{l}\text { Exosome isola- } \\
\text { tion method }\end{array}$ & $\begin{array}{l}\text { miRNA isolation } \\
\text { method }\end{array}$ & $\begin{array}{l}\text { miRNA-related } \\
\text { experiment }\end{array}$ & Highlighted miRNAs & Potential biomarker & Other information \\
\hline & & & & & $\begin{array}{l}\text { miR-378a-3p, miR-451a, and } \\
\text { miR-342-3p }\end{array}$ & & \\
\hline $\begin{array}{l}\text { Ramachandran } \\
\text { et al., } 2017\end{array}$ & $100 \mu$ l plasma & ExoQuick' & $\begin{array}{l}\text { SeraMir RNA } \\
\text { isolation kit' }\end{array}$ & Ross score & miR-129-p & $\begin{array}{l}\text { Heart failure (HF) in } \\
\text { univentricular heart disease } \\
\text { independent of ventricular } \\
\text { morphology or stage of } \\
\text { palliation }\end{array}$ & $\begin{array}{l}\text { miRNA level is inversely related to the degree } \\
\text { of clinical heart failure as assessed by Ross } \\
\text { score }\end{array}$ \\
\hline $\begin{array}{l}\text { Melman et al., } \\
2015\end{array}$ & Plasma & UC & $\begin{array}{l}\text { mirVana PARIS } \\
\text { RNA isolation kit }\end{array}$ & $\begin{array}{l}\text { 1. Megaplex miRNA } \\
\text { primer pool } \\
\text { 2. RT-qPCR }\end{array}$ & miR-30d & HF disease management & $\begin{array}{l}\text { Upregulation of miRNA in coronary sinus (CS) } \\
\text { patient with } \mathrm{HF}\end{array}$ \\
\hline $\begin{array}{l}\text { Perge et al., } \\
2017\end{array}$ & $200 \mu$ pl plasma & $\begin{array}{l}\text { Total exosome } \\
\text { isolation (from } \\
\text { plasma) kit } / \mathrm{UC}\end{array}$ & $\begin{array}{l}\text { Total exosome } \\
\text { RNA and protein } \\
\text { isolation kit// } \\
\text { MinElute cleanup it }\end{array}$ & $\begin{array}{l}\text { 1. miRNA profiling: } \\
\text { Megaplex pools } \\
\text { 2. RT-qPCR }\end{array}$ & miR-483-5p & $\begin{array}{l}\text { Adrenocortical cancer (ACC) } \\
\text { vs. adrenocortical adenomas } \\
\text { (ACA) } \\
\text { preoperative diagnosis of } \\
\text { ACC }\end{array}$ & $\begin{array}{l}\text { Upregulation of miRNA in ACC compared to } \\
\text { ACA, with AUC } 0.965 \text {, sensitivity of } 87.5 \% \text {, } \\
\text { and specificity } 94.45\end{array}$ \\
\hline $\begin{array}{l}\text { Murray et al., } \\
2017\end{array}$ & $800 \mu \mathrm{l} \mathrm{serum}$ & PEG & Trizol LS' & RT-qPCR & miR-122 and miR-200a & Liver disease & $\begin{array}{l}\text { Upregulation of miRNAs in anti-retroviral } \\
\text { therapies (ART)-treated, HIV-1 infected } \\
\text { individuals prior to the development of fatal } \\
\text { liver disease }\end{array}$ \\
\hline $\begin{array}{l}\text { Momen-Heravi } \\
\text { et al., } 2015\end{array}$ & $150 \mu$ l plasma & ExoQuicki & $\begin{array}{l}\text { QIAzol Lysis + } \\
\text { Direct-zol'TM RNA } \\
\text { MiniPrep isolation } \\
\text { kit }^{m}\end{array}$ & $\begin{array}{l}\text { 1. Microarray }{ }^{n} \\
\text { 2. RT-qPCR }\end{array}$ & miR-30a and miR-192 & Liver disease & $\begin{array}{l}\text { 1. Upregulation of miRNAs in alcoholic patients } \\
\text { 2. miRNA-192 has AUC }=0.95 ; p<0.001\end{array}$ \\
\hline $\begin{array}{l}\text { Sugimachi } \\
\text { et al., } 2015\end{array}$ & $\begin{array}{l}\text { Serum: } \\
1500 \mu l \text { (microarray) } \\
\text { and } 300 \mu l \text { for RT- } \\
\text { qPCR }\end{array}$ & $\begin{array}{l}\text { Filtration through } \\
0.22-\mathrm{mm} \text { filter + UC }\end{array}$ & miRNeasy mini kit ${ }^{\dagger}$ & $\begin{array}{l}\text { 1. Microarray (3D- } \\
\text { gene human } \\
\text { miRNA oligo chips) } \\
\text { 2. RT-qPCR }\end{array}$ & miR-718 & $\begin{array}{l}\text { Recurrence and therapeutic } \\
\text { targets of hepatocellular } \\
\text { carcinoma (HCC) }\end{array}$ & $\begin{array}{l}\text { Downregulation in patients with tumor } \\
\text { recurrence after liver transplant (LT) }\end{array}$ \\
\hline $\begin{array}{l}\text { Liu et al., } \\
2017 a\end{array}$ & $300 \mu$ pl plasma & ExoQuick' & NA & $\begin{array}{l}\text { 1. miRNA profiling }{ }^{\circ} \\
\text { 2. RT-qPCR }\end{array}$ & $\begin{array}{l}\text { miR-10b-5p, miR-21-5p, and } \\
\text { miR-23b-3p }\end{array}$ & $\begin{array}{l}\text { Non-small-cell lung cancer } \\
\text { (NSCLC) }\end{array}$ & $\begin{array}{l}\text { Upregulation of miRNAs were independently } \\
\text { associated with poor survival in NSCLC } \\
\text { patients }\end{array}$ \\
\hline \multirow[t]{2}{*}{$\begin{array}{l}\text { Cazzoli et al., } \\
2013\end{array}$} & $500 \mu$ pl plasma & ExoQuicki & $\begin{array}{l}\text { Rneasy Lysis Buffer } \\
\text { RLT }^{\dagger}+\text { Trizol }\end{array}$ & qRT-PCR & $\begin{array}{l}\text { miR-139-5p, } \\
\text { miR-200b-5p, } \\
\text { miR-378a, and } \\
\text { miR-379 }\end{array}$ & $\begin{array}{l}\text { Screening test: } \\
\text { nodule (lung adeno- } \\
\text { carcinomas } \\
\text { +carcinoma) vs. non-nodule } \\
\text { (healthy former smokers) } \\
\text { lung adeno-carcinomas + } \\
\text { carcinoma }\end{array}$ & $\begin{array}{l}97.5 \% \text { sensitivity, } 72 \% \text { specificity, and AUC } \\
\text { ROC of } 90.8 \%\end{array}$ \\
\hline & & & & & $\begin{array}{l}\text { miR-30a-3p, miR-100, } \\
\text { miR-151a-5p, miR-154-3p, } \\
\text { and miR-200b-5p }\end{array}$ & $\begin{array}{l}\text { Diagnostic test: Only nodule } \\
\text { population } \\
\text { Lung adenocarcinoma vs. } \\
\text { granuloma }\end{array}$ & $\begin{array}{l}96 \% \text { sensitivity, } 60 \% \text { specificity, and AUC } \\
\text { ROC of } 76 \%\end{array}$ \\
\hline
\end{tabular}




\begin{tabular}{|c|c|c|c|c|c|c|c|}
\hline Reference & Source & $\begin{array}{l}\text { Exosome isola- } \\
\text { tion method }\end{array}$ & $\begin{array}{l}\text { miRNA isolation } \\
\text { method }\end{array}$ & $\begin{array}{l}\text { miRNA-related } \\
\text { experiment }\end{array}$ & Highlighted miRNAs & Potential biomarker & Other information \\
\hline $\begin{array}{l}\text { Kobayashi } \\
\text { et al., } 2017\end{array}$ & $\begin{array}{l}1000 \mu \mathrm{ll} \text { unsti- } \\
\text { mulated whole } \\
\text { saliva }\end{array}$ & $\begin{array}{l}\text { Total exosome } \\
\text { isolation reagent }\end{array}$ & $\begin{array}{l}\text { Total exosome } \\
\text { RNA and protein } \\
\text { isolation kits }\end{array}$ & $\begin{array}{l}\text { 1. PCR array } \\
\text { analyses and data } \\
\text { analysis: } \\
\text { neuropathic and } \\
\text { inflammatory } \\
\text { miScript miRNAs } \\
\text { PCR array } \\
\text { 2. RT-qPCR }\end{array}$ & miR203a-3p & $\begin{array}{l}\text { Low oral health-related quality } \\
\text { of life (OHRQoL) group vs. } \\
\text { high-OHRQoL }\end{array}$ & Upregulation of miRNA in low-OHRQoL \\
\hline $\begin{array}{l}\text { Kangas et al., } \\
2017\end{array}$ & $450 \mu l$ serum & ExoQuick' & Trisure reagent & $\begin{array}{l}\text { 1. qPCR } \\
\text { 2. small RNA } \\
\text { sequencing } \\
\text { 3. RT-qPCR }\end{array}$ & $\begin{array}{l}\text { miR-27-3p, miR-28-3p, miR- } \\
\text { 30a-5p, miR-106-5p, miR- } \\
\text { 126-5p, and miR-148a-3p }\end{array}$ & $\begin{array}{l}\text { Metabolic and inflammatory } \\
\text { status as a result of hormonal } \\
\text { changes at menopause }\end{array}$ & $\begin{array}{l}\text { miRNA levels significantly associated with } \\
\text { serum } 17 \beta \text {-estradiol }\end{array}$ \\
\hline $\begin{array}{l}\text { Domanska- } \\
\text { Senderowska } \\
\text { et al., } 2017\end{array}$ & $200 \mu \mathrm{l} \mathrm{serum}$ & $\begin{array}{l}\text { Total exosome } \\
\text { isolation reagent } \\
\text { (from serum) }\end{array}$ & $\begin{array}{l}\text { Total exosome } \\
\text { RNA and protein } \\
\text { isolation } \text { kit }^{\mathrm{e}}\end{array}$ & RT-qPCR & miR-27b and miR-29 & Cardio-respiratory fitness & Upregulation of miRNAs \\
\hline $\begin{array}{l}\text { Chen et al., } \\
2017\end{array}$ & $500 \mu \mathrm{l} \mathrm{serum}$ & ExoQuick & miRNeasy mini kit ${ }^{f}$ & qPCR & miR-223 & $\begin{array}{l}\text { Acute ischemic stroke } \\
\text { occurrence, stroke severity, } \\
\text { and short-term outcomes }\end{array}$ & Upregulation of miRNAs \\
\hline $\begin{array}{l}\text { Yuan et al., } \\
2016\end{array}$ & plasma & $\begin{array}{l}\text { ExoQuick' } \\
+ \\
\text { RNAse A }\end{array}$ & miRNeasy micro kit $^{f}$ & $\begin{array}{l}\text { Small RNA } \\
\text { sequencing }\end{array}$ & miR-125a and miR-1343-3p & $\begin{array}{l}\text { Colon cancer; prostate } \\
\text { cancer including castration- } \\
\text { resistant and hormone- } \\
\text { sensitive; pancreatic cancer }\end{array}$ & $\begin{array}{l}\text { 1. Down-regulation with all cancer types tested } \\
\text { with }<0.05 \text { false rate } \\
\text { 2. AUC } 0.68 \text { to } 0.92 \text {, depends on cancer type } \\
\text { and stage }\end{array}$ \\
\hline $\begin{array}{l}\text { Meng et al., } \\
2016\end{array}$ & $600 \mu \mathrm{l}$ serum & $\begin{array}{l}\text { Total exosome } \\
\text { isolation reagent for } \\
\text { serum }^{e}\end{array}$ & mirVana PARIS kit ${ }^{\mathrm{e}}$ & $\mathrm{RT}-\mathrm{qPCR}$ & miR-373 & $\begin{array}{l}\text { More aggressive breast } \\
\text { carcinomas }\end{array}$ & Association of levels with triple negative \\
\hline $\begin{array}{l}\text { Hannafon et al., } \\
2016\end{array}$ & Plasma & ExoQuicki & TRIzol & $\begin{array}{l}\text { 1. Next-generation } \\
\text { sequencing }{ }^{\mathrm{C}} \\
\text { 2. RT-qPCR }\end{array}$ & $\begin{array}{l}\text { miR-21 and } \\
\text { miR-1246 }\end{array}$ & $\begin{array}{l}\text { Breast cancer (accompany } \\
\text { another diagnostic tool) }\end{array}$ & AUC $0.73(95 \% \mathrm{Cl} 0.53,0.92 ; \mathrm{P}=0.022)$ \\
\hline $\begin{array}{l}\text { Khalyfa et al., } \\
2016\end{array}$ & Plasma & $\begin{array}{l}\text { Total exosome } \\
\text { isolation reagent }\end{array}$ & miRNeasy mini kit ${ }^{f}$ & Microarrays $^{h}$ & hsa-miR-483-3p & $\begin{array}{l}\text { Intermittent hypoxia }(\mathrm{IH}) \\
\text { exposure }\end{array}$ & Exosomal role as cell-to-cell communicator \\
\hline $\begin{array}{l}\text { Alhasan et al., } \\
2016\end{array}$ & $1000 \mu \mathrm{l}$ serum & ExoQuick & $\begin{array}{l}\text { mirVana PARIS } \\
\text { miRNA isolation kit }\end{array}$ & $\begin{array}{l}\text { 1. miRNA profiling } \\
\text { (scano-miR } \\
\text { platform) } \\
\text { 2. RT-qPCR }\end{array}$ & $\begin{array}{l}\text { Prostate cancer (Pca) } \\
\text { miRNAs: } \\
\text { miR-106a, miR-135a*, miR- } \\
\text { 200c, miR-433, and miR-605 }\end{array}$ & $\begin{array}{l}\text { Very high-risk (VHR) Pcas } \\
\text { patients vs. low-risk patients } \\
\text { and healthy subjects VHR } \\
\text { aggressive Pca }\end{array}$ & $\begin{array}{l}\text { Differentiate population with at least } 89 \% \\
\text { accuracy }\end{array}$ \\
\hline $\begin{array}{l}\text { Huang et al., } \\
2015\end{array}$ & $250 \mu \mathrm{l}$ plasma & $\begin{array}{l}\text { ExoQuick'+ } \\
\text { RNase A }\end{array}$ & miRNeasy micro kit ${ }^{f}$ & RT-qPCR & miR-375 and miR-1290 & $\begin{array}{l}\text { Castration-resistant prostate } \\
\text { cancer (CRPC) }\end{array}$ & $\begin{array}{l}\text { Upregulation of miRNAs significantly } \\
\text { associated with overall survival }\end{array}$ \\
\hline $\begin{array}{l}\text { Ramezani et al., } \\
2015\end{array}$ & $1000 \mu \mathrm{L}$ urine & $\begin{array}{l}\text { Exosome RNA } \\
\text { isolation kit }\end{array}$ & NA & $\begin{array}{l}\text { 1. Microarrays } \\
\text { 2. RT-qPCR }\end{array}$ & $\begin{array}{l}\text { miR-30b, } \\
\text { miR-30c, } \\
\text { miR-34b, } \\
\text { miR-34c, and miR-342 } \\
\text { miR-1225-5p } \\
\text { miR-1915 and miR-663 } \\
\text { miR-155 }\end{array}$ & $\begin{array}{l}\text { Minimal change disease } \\
\text { (MCD) patients vs. } \\
\text { focal glomerulo-sclerosis } \\
\text { (FSGS) patients and control } \\
\text { subjects } \\
\text { FSGS vs. MCD and control } \\
\text { subjects }\end{array}$ & $\begin{array}{l}\text { Downregulation of miRNAs } \\
\text { Upregulation of miRNAs }\end{array}$ \\
\hline
\end{tabular}


(IGFBP-1), as a biomarker for the early detection of gastrointestinal cancer]. Alteration in biomarker concentration, structure, function, or action can be associated with the onset, progression, or even regression of a particular disorder as a result of how the body responds to it (Gill et al., 2017).

A biomarker needs to pass several tests before it can be successfully used clinically. These tests are (1) preclinical testing, performed using patient samples and confirmed at the in vitro and in vivo levels, (2) feasibility analysis, which involves the usage of small patient subpopulations to demonstrate the ability to discriminate diseased from healthy subjects, (3) the validation process, which is used to confirm that the biomarker has been assayed properly, and (4) statistical analysis, which is carried out to evaluate the discriminatory accuracy of the biomarker in a large patient population (Gill et al., 2017).

\section{MICRORNA (MIRNA)}

\section{Origin}

miRNAs can originate from intergenic or intragenic (both exonic and intronic) genomic regions, transcribed into long primary transcripts called pri-miR, which are folded back and form double-stranded hairpin structures. The pri-miR will be subjected to a sequential process to produce miRNAs. First is the production of precursor molecules called pre-miR (80-120 nucleotides) in the nucleus by type III endonuclease DROSHA. These pre-miRs are then exported to the cytoplasm, mediated by EXPORTINS, and are later processed by another type of endonuclease, DICER, into short "active" molecules called miRNAs (Redis et al., 2012). These mature miRNAs will then be integrated into the RNA-induced silencing complex (RISC) to exhibit their role as gene expression regulators (Mo et al., 2012; O'Brien et al., 2018).

\section{Source of Circulating miRNAs}

Circulating miRNAs, which are found in body fluids such as in saliva, serum, plasma, and milk, can be secreted or produced as a result of various events, such as (1) passive leakage from cells that suffer injury, chronic inflammation, apoptosis, or necrosis, or perhaps from cells with a short half-life like platelets, (2) active secretion via cell-derived membrane vesicles such as microparticles (MPs), exosomes, shedding vesicles, and apoptotic bodies, and (3) active secretion by a protein-miRNA complex, whereby miRNAs build an association with either or both of lipoproteins (e.g., high-density lipoprotein: HDL) and Argonaute protein (e.g., Ago2) (Redis et al., 2012).

\section{Factors Contributing to the Stability of Circulating miRNAs and lts Benefits to Biomarker Development}

Circulating miRNAs are unusually stable due to (1) their packaging in vesicles, such as in exosomes (Chugh et al., 2013) or apoptotic bodies, (2) their RNA folding and size, and/or (3) their presence in Ago-containing ribonucleic acid: protein (RNP) complexes (Chugh et al., 2013), with nucleophosmin (Kubiczkova et al., 2014), or with high-density lipoproteins 
TABLE 3 | Summary of articles with comparable performance between exosomal, non-exosomal circulating miRNAs, and unfractioned miRNA samples as potential biomarkers.

\begin{tabular}{|c|c|c|c|c|c|c|c|}
\hline Reference & Sources of miRNAs & $\begin{array}{l}\text { Exosomal \& non- } \\
\text { exosomal isolation } \\
\text { method }\end{array}$ & $\begin{array}{l}\text { miRNA isolation } \\
\text { method }\end{array}$ & $\begin{array}{l}\text { miRNA-related } \\
\text { experiment }\end{array}$ & Highlighted miRNAs & $\begin{array}{l}\text { Better miRNA source } \\
\text { according to findings }\end{array}$ & $\begin{array}{l}\text { Potential bio- } \\
\text { marker }\end{array}$ \\
\hline $\begin{array}{l}\text { Van Eijndhoven } \\
\text { et al., } 2016\end{array}$ & $\begin{array}{l}\text { Tumor cells vs. whole plasma vs. } \\
\text { EVs plasma }\end{array}$ & $\begin{array}{l}\text { Size exclusion } \\
\text { chromate-graphy } \\
\text { (SEC) }\end{array}$ & Trizol-LS & $\begin{array}{l}\text { 1. Small RNA } \\
\text { sequencing }^{\mathrm{C}} \\
\text { 2. Multiplex stem-loop } \\
\text { RT-PCR }\end{array}$ & $\begin{array}{l}\text { miR-24-3p, miR-127-3p, } \\
\text { miR-21-5p, miR-155-5p, and } \\
\text { let-7a-5p }\end{array}$ & EV plasma & $\begin{array}{l}\text { Hodgkin's } \\
\text { disease }\end{array}$ \\
\hline Beg et al., 2017 & $\begin{array}{l}(200 \mu l): \\
\text { whole plasma vs. exosomal plasma }\end{array}$ & $\begin{array}{l}\text { Exosome RNA } \\
\text { isolation kit }\end{array}$ & $\begin{array}{l}\text { mirVana miRNA } \\
\text { isolation } \mathrm{kit}^{\mathrm{e}}\end{array}$ & RT-qPCR & $m i R-146 a$ & Exosomal plasma & $\begin{array}{l}\text { Heart failure } \\
\text { (HF) }\end{array}$ \\
\hline $\begin{array}{l}\text { Crossland et al., } \\
2017\end{array}$ & $\begin{array}{l}(250 \mu l) \text { : } \\
\text { whole serum vs. exosomal serum }\end{array}$ & $\begin{array}{l}\text { Total exosome } \\
\text { isolation reagent' }\end{array}$ & Total RNA Isolation kit' & RT-qPCR & $\begin{array}{l}\text { miR-423, miR-199 and miR- } \\
93^{*}\end{array}$ & Exosomal serum & $\begin{array}{l}\text { Acute graft- } \\
\text { versus-host } \\
\text { disease }\end{array}$ \\
\hline $\begin{array}{l}\text { de Gonzalo-Calvo } \\
\text { et al., } 2017\end{array}$ & $\begin{array}{l}\text { Whole serum } \\
\text { validated with cultured cells vs. } \\
\text { exosomal conditioned media }\end{array}$ & NA & mirVana kit ${ }^{e}$ & RT-qPCR & $\mathrm{miR}-1$ and $\mathrm{miR}-133 \mathrm{a}$ & Whole serum & $\begin{array}{l}\text { Subclinical } \\
\text { diabetic cardio- } \\
\text { myopathy }\end{array}$ \\
\hline $\begin{array}{l}\text { Endzeliņ̌s et al., } \\
2017\end{array}$ & $\begin{array}{l}(400 \mu \text { I): } \\
\text { whole plasma vs. EV plasma }\end{array}$ & SEC & $\begin{array}{l}\text { Modified miRN-easy } \\
\text { Micro Kit } \\
5 \text { volumes of QIAzol } \\
\text { Lysis }\end{array}$ & RT-qPCR & $\begin{array}{l}\text { miR-375 } \\
\text { miR-200c-3p and miR-21-5p }\end{array}$ & $\begin{array}{l}\text { Whole plasma } \\
\text { EV plasma }\end{array}$ & $\begin{array}{l}\text { Prostate cancer } \\
\text { (Pca) vs. benign } \\
\text { prostatic } \\
\text { hyperplasia }\end{array}$ \\
\hline Li et al., 2016 & $\begin{array}{l}(400 \mathrm{ml}) \text { : } \\
\text { whole serum vs. exosomal serum }\end{array}$ & ExoQuicki & $\begin{array}{l}\text { miRNeasy serum/ } \\
\text { plasma kit }^{\dagger}\end{array}$ & RT-qPCR & $\operatorname{miR}-141$ & Exosomal serum & Pca \\
\hline $\begin{array}{l}\text { Fujiwara et al., } \\
2017\end{array}$ & $\begin{array}{l}800 \mu l \text { whole serum } \\
\text { validated using cell culture and } \\
\text { exosomal conditioned media }\end{array}$ & NA & 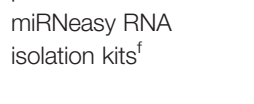 & $\begin{array}{l}\text { 1. Microarray }{ }^{h} \\
\text { 2. RT-qPCR }\end{array}$ & miR-17-5p and miR-25-3p & $\begin{array}{l}\text { Whole serum: } \\
\text { based on validated cultured } \\
\text { studies }\end{array}$ & Osteosarcoma \\
\hline Huang et al.,2017 & $\begin{array}{l}\text { Tissues, } \\
200 \mu \mathrm{l} \\
\text { arterial whole serum, } 200 \mu \mathrm{l} \\
\text { exosomal serum }\end{array}$ & ExoQuick' & $\begin{array}{l}\text { mirVana } \\
\text { PARIS kit }\end{array}$ & RT-qPCR & $\begin{array}{l}\text { MiR-20b-5p, miR-28-3p, and } \\
\text { miR-192-5p }\end{array}$ & $\begin{array}{l}\text { Similar performance; need } \\
\text { thorough study using other } \\
\text { vesicles and complexes to } \\
\text { make comparisons }\end{array}$ & $\begin{array}{l}\text { esophageal } \\
\text { squamous cell } \\
\text { carcinoma } \\
\text { (ESCC) }\end{array}$ \\
\hline Khare et al., 2017 & $\begin{array}{l}425 \mu \text { l whole plasma vs. exosomal } \\
\text { plasma }\end{array}$ & UC & $\begin{array}{l}\text { RNeasy MinElute } \\
\text { columns }^{\dagger}\end{array}$ & $\begin{array}{l}\text { Small RNA } \\
\text { sequencing }\end{array}$ & $\begin{array}{l}\text { miR-12, miR-23a, miR-25, } \\
\text { miR-26b, miR-30a, miR-30d, } \\
\text { miR-93, miR-140*, miR-122, } \\
\text { miR-144, miR-182, and miR- } \\
186\end{array}$ & Whole plasma & $\begin{array}{l}\text { Relapse } \\
\text { lymphoma }\end{array}$ \\
\hline Liu et al., 2017b & $\begin{array}{l}\text { Whole serum vs. exosomal serum } \\
\text { vs. cell-free serum }\end{array}$ & ExoQuick' & $\begin{array}{l}\text { mirVana }{ }^{T M} \text { miRNA } \\
\text { isolation kite }\end{array}$ & RT-qPCR & $\mathrm{miR}-125 b$ & Exosomal serum & $\begin{array}{l}\text { Recurrence and } \\
\text { survival of } \\
\text { hepatocellular } \\
\text { carcinoma } \\
\text { (HCC) }\end{array}$ \\
\hline Fornari et al., 2015 & $\begin{array}{l}(400 \mu l) \text { : } \\
\text { exosomal serum vs. non-exosomal } \\
\text { serum }\end{array}$ & NA & Trizol reagent' & $\begin{array}{l}\text { 1. Microarray } \\
\text { 2. RT-qPCR }\end{array}$ & $\begin{array}{l}\text { miR-519d, miR-21, and miR- } \\
221\end{array}$ & Exosomal serum & $\mathrm{HCC}$ \\
\hline Sohn et al., 2015 & $\begin{array}{l}(500 \mu l) \text { : } \\
\text { whole serum vs. exosomal serum }\end{array}$ & ExoQuick' & $\begin{array}{l}\text { miRNeasy serum/ } \\
\text { plasma kit }^{\dagger}\end{array}$ & RT-qPCR & $\begin{array}{l}\text { miR-18a, miR-101, miR- } \\
\text { 106b, miR-122, miR-195, } \\
\text { miR-221, miR-222, and miR- } \\
224\end{array}$ & Exosomal serum & $\mathrm{HCC}$ \\
\hline Moen et al., 2017 & Cells vs. $200 \mu \mathrm{l}$ exosomal serum & NA & $\begin{array}{l}\text { miRNeasy serum } \\
\text { plasma isolation kit }\end{array}$ & RT-qPCR & $\begin{array}{l}\text { miR-223, miR-760, and miR- } \\
145\end{array}$ & $\begin{array}{l}\text { Exosomal miRNAs showed to } \\
\text { be released from cells asso- } \\
\text { ciated with upregulation of } \\
\text { inflammation }\end{array}$ & $\begin{array}{l}\text { Chronic lumbar } \\
\text { radicular pain }\end{array}$ \\
\hline
\end{tabular}




\begin{tabular}{|c|c|c|c|c|c|c|c|}
\hline Reference & Sources of miRNAs & $\begin{array}{l}\text { Exosomal \& non- } \\
\text { exosomal isolation } \\
\text { method }\end{array}$ & $\begin{array}{l}\text { miRNA isolation } \\
\text { method }\end{array}$ & $\begin{array}{c}\text { miRNA-related } \\
\text { experiment }\end{array}$ & Highlighted miRNAs & $\begin{array}{l}\text { Better miRNA source } \\
\text { according to findings }\end{array}$ & $\begin{array}{l}\text { Potential bio- } \\
\text { marker }\end{array}$ \\
\hline $\begin{array}{l}\text { Rabinowits et al., } \\
2017\end{array}$ & $\begin{array}{l}\text { Tissues vs. exosomal plasma vs. } \\
\text { cell-free plasma }\end{array}$ & ExoQuick & TRIzol reagent & $\begin{array}{l}\text { TaqMan-based miRNA } \\
\text { profiling: TaqMan array } \\
\text { human miRNA } \\
\text { platform }\end{array}$ & $\begin{array}{l}\text { hsa-miR-19a, hsa-miR-512- } \\
\text { 3p, hsa-miR-27b, hsa-miR- } \\
\text { 20a, hsa-miR-28-3p, hsa- } \\
\text { miR-200c, hsa-miR-151-3p, } \\
\text { hsa-miR-223, hsa-miR-20b, } \\
\text { hsa-miR-22, hsa-miR-516- } \\
\text { 3p, hsa-miR-370, hsa- } \\
\text { miR139-5p, hsa-miR-145-3p, } \\
\text { hsa-let-7e, and hsa-miR-30c }\end{array}$ & Exosomal plasma & $\begin{array}{l}\text { Squamous cell } \\
\text { carcinoma }\end{array}$ \\
\hline $\begin{array}{l}\text { Reithmair et al., } \\
2017\end{array}$ & $\begin{array}{l}3000 \mu \text { l: whole blood vs. whole } \\
\text { serum vs. exosomal serum }\end{array}$ & 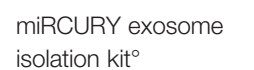 & $\begin{array}{l}\text { miRCURY RNA } \\
\text { isolation kit-biofluids }\end{array}$ & $\begin{array}{l}\text { Next-generation } \\
\text { sequencing }^{C}\end{array}$ & $\begin{array}{l}\text { miR-193a-5p and miR-125- } \\
5 p\end{array}$ & Exosomal serum & Septic shock \\
\hline Uotani et al., 2017 & $\begin{array}{l}(200 \mu) \text { : } \\
\text { exosomal serum vs. Ago2 } \\
\text { complexes }\end{array}$ & SEC & MiRNeasy mini kits ${ }^{\dagger}$ & $\begin{array}{l}\text { 1. Microarray } \\
\text { 2. RT-qPCR }\end{array}$ & miR-92B-3p & Exosomal serum & $\begin{array}{l}\text { Synovial } \\
\text { sarcoma (SS) }\end{array}$ \\
\hline Yokoi et al., 2017 & $\begin{array}{l}200 \mu \mathrm{L} \\
(\mathrm{RT}-\mathrm{gPCR}) / \\
600 \mu \mathrm{L} \\
\text { (NGS): whole serum } \\
\text { validated in exosomal conditioned } \\
\text { media vs. cultured cells }\end{array}$ & NA & $\begin{array}{l}\text { QIAzol and the } \\
\text { miRNeasy mini kit }\end{array}$ & $\begin{array}{l}\text { 1. Small RNA } \\
\text { sequencing } \\
\text { 2. RT-qPCR }\end{array}$ & $\begin{array}{l}\text { miR-142-3p, miR-26a-5p, } \\
\text { miR-374a-5p, miR-766-3p, } \\
\text { miR-200a-3p, miR-328-3p, } \\
\text { miR-130b-3p, and let-7d-5p }\end{array}$ & $\begin{array}{l}\text { Circulating miRNAs in whole } \\
\text { serum were believed to be } \\
\text { exosomal-originated }\end{array}$ & Ovarian cancer \\
\hline Dinh et al., 2016 & $\begin{array}{l}(200 \mu \mathrm{l}) \text { : whole plasma } \\
\text { validated with cultured cells vs. } \\
\text { exosomal conditioned media }\end{array}$ & NA & $\begin{array}{l}\text { Exiqon miRCURY } \\
\text { biofluids total RNA } \\
\text { isolation kits }\end{array}$ & $\begin{array}{l}\text { 1. miRNA profiling } \\
\text { 2. RT-qPCR }\end{array}$ & miR-29a-3p, miR-150-5p & Whole plasma & $\begin{array}{l}\text { Thoracic } \\
\text { radiation } \\
\text { therapy for non } \\
\text { small cell lung } \\
\text { cancer }\end{array}$ \\
\hline $\begin{array}{l}\text { Emanueli et al., } \\
2016\end{array}$ & $\begin{array}{l}(100 \mu \mathrm{l}) \text { : } \\
\text { whole plasma vs. exosomal plasma }\end{array}$ & $\begin{array}{l}\text { Exo-spin } \\
\text { mini-columns }\end{array}$ & miRNeasy kit ${ }^{f}$ & microRNA analyses & $\begin{array}{l}\text { Cardiac expressed miRs: } \\
\text { miR-1, miR-24, miR-133a/b, } \\
\text { miR-208a/b, and miR-210 } \\
\text { Non-vascular miR-122 }\end{array}$ & Exosomal plasma & $\begin{array}{l}\text { Myocardial } \\
\text { damage }\end{array}$ \\
\hline Uratani et al., 2016 & $\begin{array}{l}(250 \mu \mathrm{l}) \text { : } \\
\text { whole serum vs. exosomal serum }\end{array}$ & ExoQuick ${ }^{i}$ & $\begin{array}{l}\text { miRNeasy } \\
\text { kit }^{f}\end{array}$ & $R T-q P C R$ & $\begin{array}{l}\text { miR-21, miR-29a, and miR- } \\
92 a\end{array}$ & Whole serum & $\begin{array}{l}\text { Large } \\
\text { adenomatous } \\
\text { polyps }\end{array}$ \\
\hline Pirola et al., 2015 & $\begin{array}{l}(200 \mu l) \text { : } \\
\text { whole serum vs. Ago } 2 \text { complexes } \\
\text { serum vs. cell-free and Ago2-free } \\
\text { serum }\end{array}$ & NA & $\begin{array}{l}\text { miRNeasy serum/ } \\
\text { plasma kit }^{f}\end{array}$ & $\begin{array}{l}\text { 1. Global profiling } \\
\text { 2. In-situ hybridization } \\
\text { (ISH) } \\
\text { 3. RT-PCR } \\
\text { 4. Cell culture and } \\
\text { transfection }\end{array}$ & miR-122 & Ago2-free serum & $\begin{array}{l}\text { Non-alcoholic } \\
\text { fatty liver } \\
\text { disease } \\
\text { (NAFLD) }\end{array}$ \\
\hline Ragusa et al., 2015 & $\begin{array}{l}\text { Vitreous humor }(V H) \text { vs. exosomal } \\
\text { VH vs. } \\
(400 \mu \mathrm{L}) \text { : } \\
\text { whole serum vs. exosomal serum }\end{array}$ & UC & miRNeasy mini kit ${ }^{f}$ & $\begin{array}{l}\text { miRNA profiling } \\
\text { (TaqMan low density } \\
\text { array) }\end{array}$ & $\operatorname{miR} 146 a$ & Similar expression & $\begin{array}{l}\text { Uveal } \\
\text { melanoma (UM) }\end{array}$ \\
\hline $\begin{array}{l}\text { Eichelser et al., } \\
2014\end{array}$ & $\begin{array}{l}(400 \mu \mathrm{L}) \text { : } \\
\text { whole serum vs. exosomal serum } \\
\text { vs. cell-free serum }\end{array}$ & ExoQuicki & mirVana PARIS kit ${ }^{\mathrm{e}}$ & $\begin{array}{l}\text { 1. } \mathrm{qRT}-\mathrm{PCR} \\
\text { 2. Luciferase assay }\end{array}$ & miR-101 and miR-373 & Exosomal serum & $\begin{array}{l}\text { Aggressive } \\
\text { breast } \\
\text { carcinomas }\end{array}$ \\
\hline
\end{tabular}




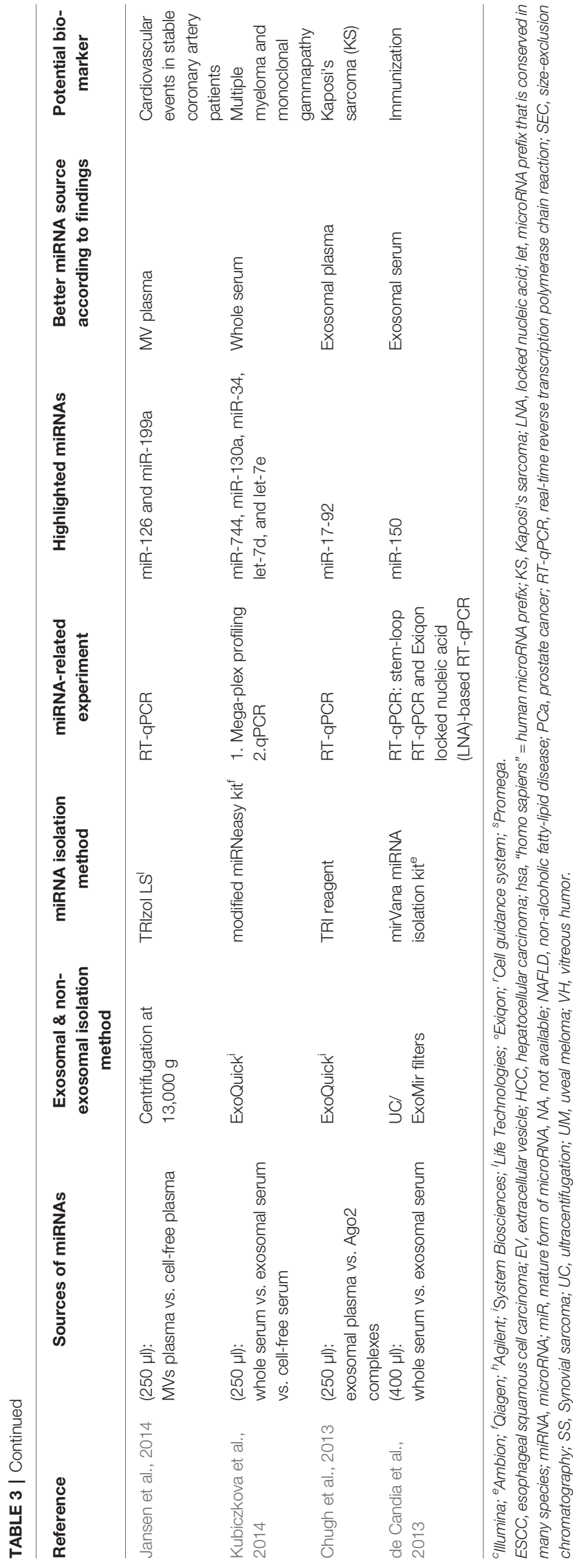

(HDL) (Köberle et al., 2013; Fornari et al., 2015). The stability of miRNAs results from their resistance toward the action of ribonucleases (Jansen et al., 2014; Dinh et al., 2016; Beg et al., 2017; Liu et al., 2017a; Yokoi et al., 2017; de Candia et al., 2013; Li et al., 2012). This stability means that they are long-lived in biological fluids (Ragusa et al., 2015; Emanueli et al., 2016) and are therefore proposed as attractive diagnostic (Pirola et al., 2015) and prognostic biomarkers (Fornari et al., 2015). Their easy accessibility through the collection of body fluids such as blood derivatives, saliva, or urine also points toward their being an ideal source for miRNA biomarkers (Gallo et al., 2012). Several experimental studies have also reported resistance of endogenous circulating miRNAs toward severe stressing conditions, such as high temperatures, repeated freeze-thaw cycles (Fornari et al., 2015), very low or high pH levels (Duttagupta et al., 2011), boiling, and extended storage time (Uratani et al., 2016; Domańska-Senderowska et al., 2017; Fu et al., 2018), which are positive traits for circulating miRNAs as potential biomarkers.

Non-invasive or minimally invasive collection of circulating miRNAs (Duttagupta et al., 2011; Pirola et al., 2015; Ragusa et al., 2015; Dinh et al., 2016; Uratani et al., 2016; Perge et al., 2017) enables (1) the prevention of repetitive invasive procedures such as tissue biopsy (e.g., liver biopsy in detecting hepatocellular carcinoma (HCC) (Sohn et al., 2015), dangerous kidney biopsy in distinguishing minimal change disease (MCD) from focal segmental glomerulosclerosis (FSGS) (Ramezani et al., 2015), or bone marrow procedures (Kubiczkova et al., 2014), (2) the avoidance of possible difficulties in obtaining real samples from cirrhotic patients with liver nodules of uncertain malignancy that are identified via imaging techniques (Fornari et al., 2015), and (3) the avoidance of sampling limitations such lesions being too small to be biopsied and studied using conventional methods (Ramezani et al., 2015).

The availability and easy accessibility of circulating miRNAs enables them to be substitutes for existing tedious and expensive procedures that require a high degree of expertise such as X-ray, computed tomography (CT), positron emission tomography (PET)-CT, magnetic resonance imaging (MRI) (Fujiwara et al., 2017), sigmoidoscopy, colonoscopy (Uratani et al., 2016), ophthalmoscopy, ultrasonography, fundus fluorescein angiography, and indocyanine green angiography (Ragusa et al., 2015). In addition to this, they may fill the gaps where useful biomarkers are yet to be found, with higher specificity and sensitivity (if possible). In cases like FSGS and MCD, miRNA expression has been reported to be able to differentiate diseases that seem similar at first glance or are related to each other yet need different treatment for recovery, to avoid resistance buildup, and to avoid progression into endstage disease or, at worst, mortality. miRNAs are also able to act as (1) a real-time monitor of drug response, (2) an early detector of recurrence or metastasis, and (3) a substitute for a known serum-based tumor marker of osteosarcoma (alkaline phosphatase [ALP]) that sometimes leads to false-positive results (since ALP is generally elevated in children and affected by organ damage) in detecting and monitoring the 
TABLE 4 | Summary of articles using different sources of miRNAs in discussing subjects other than potential biomarkers of a particular disease.

\begin{tabular}{|c|c|c|c|c|c|c|c|}
\hline Reference & Sources of miRNAs & $\begin{array}{c}\text { Exosomal \& } \\
\text { non-exosomal } \\
\text { isolation method }\end{array}$ & $\begin{array}{l}\text { miRNA isolation } \\
\text { method }\end{array}$ & $\begin{array}{l}\text { miRNA-related } \\
\text { experiment }\end{array}$ & Highlighted miRNAs & $\begin{array}{l}\text { Better miRNA source } \\
\text { according to findings }\end{array}$ & Potential biomarker \\
\hline Koberle et al., 2013 & $\begin{array}{l}(200 \mu \mathrm{LL}) \text { : } \\
\text { exosomal serum vs. cell-free } \\
\text { serum }\end{array}$ & UC & miRNeasy mini Kit ${ }^{\dagger}$ & RT-qPCR & $\begin{array}{l}\text { miR-1, miR-16, miR- } \\
\text { 21, miR-122 and miR- } \\
\text { 142-3p }\end{array}$ & Exosomal serum & $\begin{array}{l}\text { 1. Exosomal miRNAs are more stable } \\
\text { than cell-free miRNAs } \\
2 \text {. RNase inhibitor can be used to } \\
\text { differentiate between exosomal and } \\
\text { cell-free miRNAs faster and more } \\
\text { easily than UC }\end{array}$ \\
\hline \multirow[t]{2}{*}{ Gallo et al., 2012} & $\begin{array}{l}\text { Whole serum vs. exosomal } \\
\text { serum vs. cell-free serum }\end{array}$ & UC & Trizol $^{q}$ & RT-qPCR & $\begin{array}{l}\text { let-7a; miR-92a, miR- } \\
\text { 142-3p, miR-101, } \\
\text { miR-16, miR-107, miR- } \\
\text { 122, miR-547, and } \\
\text { miR-768 }\end{array}$ & Exosomal serum & $\begin{array}{l}\text { Majority of miRNAs in serum and } \\
\text { saliva are concentrated in exosomes }\end{array}$ \\
\hline & $\begin{array}{l}\text { Whole saliva vs. exosomal } \\
\text { saliva vs. cell-free saliva }\end{array}$ & & & & $\begin{array}{l}\text { miR-22, miR-202, miR- } \\
\text { 203, and miR-1273d }\end{array}$ & Exosomal saliva & \\
\hline Li et al., 2012 & $\begin{array}{l}\text { Exosomal plasma vs. Ago2 } \\
\text { complexes } \\
\text { Exosomal conditioned media } \\
\text { vs. Ago2 complexes } \\
\text { conditioned media }\end{array}$ & $\begin{array}{l}\text { Differential } \\
\text { centrifugation } \\
\text { and } \\
\text { UC }\end{array}$ & $\begin{array}{l}\text { Trizol }{ }^{q /} \\
\text { miRNeasy mini kit }{ }^{\dagger}\end{array}$ & RT-qPCR & $\mathrm{miR}-16$ & Ago2 complexes & $\begin{array}{l}\text { 1. Vesicle structures such as } \\
\text { exosomes provide general protection } \\
\text { to vesicle-encapsulated miRNAs. } \\
2 \text {. Ago } 2 \text { complexes selectively } \\
\text { associated with miRNAs in vesicles } \\
\text { under functional status and protect } \\
\text { the vesicle miRNAs from degradation } \\
\text { by RNases or proteases. }\end{array}$ \\
\hline Arroyo et al., 2011 & $\begin{array}{l}\text { Exosomal plasma vs. } \\
\text { Ago2 complexes plasma }\end{array}$ & UC/SEC & miRNeasy kit ${ }^{f}$ & RT-qPCR & $\begin{array}{l}\text { miR-16, miR-92a, and } \\
\text { let-7a }\end{array}$ & $\begin{array}{l}\text { Ago2 complexes } \\
\text { plasma }\end{array}$ & $\begin{array}{l}\text { Two populations of circulating } \\
\text { miRNAs exist in plasma: Ago2 } \\
\text { complexed and vesicles (exosomes)- } \\
\text { bound; suggested that circulating } \\
\text { Ago2 complexes are a mechanism } \\
\text { responsible for the stability of plasma } \\
\text { miRNAs }\end{array}$ \\
\hline $\begin{array}{l}\text { Turchinovich et al., } \\
2011\end{array}$ & $\begin{array}{l}(400 \mu l) \text { : exosomal plasma vs. } \\
\text { Ago2 complexes plasma } \\
\text { Exosomal conditioned media } \\
\text { vs. Ago2 complexes } \\
\text { conditioned media }\end{array}$ & UC & $\begin{array}{l}\text { Tri-Reagent } L^{t}+ \\
\text { miRNeasy kit }\end{array}$ & qRT-PCR & $\begin{array}{l}\text { hsa-miR-16, has-miR- } \\
21 \text {, and has-miR-24 }\end{array}$ & $\begin{array}{l}\text { Ago2 complexes } \\
\text { plasma } \\
\text { Ago2 complexes } \\
\text { conditioned media }\end{array}$ & $\begin{array}{l}\text { Majority of nuclease-resistance } \\
\text { extracellular miRNA in plasma and cell } \\
\text { culture media is floating outside } \\
\text { exosomes and is bound to Ago } 2 \\
\text { protein }\end{array}$ \\
\hline
\end{tabular}

'Qiagen; alnvitrogen; ${ }^{\text {Sigma. }}$

Ago, Argonoute; hsa, "homo sapiens" = human microRNA prefix; let, microRNA prefix that is conserved in many species; miRNA, microRNA; miR, mature form of microRNA, NA, not available; RT-qPCR, real-time reverse transcription polymerase chain reaction; SEC, size-exclusion chromatography; UC, ultracentifugation. 
tumor burden of osteosarcoma (Fujiwara et al., 2017). Circulating miRNAs are also reported to be better markers than existing markers, for example, (1) cancer antigen-125 (CA125) measurement and ultrasonography in detecting ovarian cancer (OvCa) (Yokoi et al., 2017) or (2) squamous cell cancer antigen (SCC) and carcinoembryonic antigen (CEA) (Huang et al., 2017).

\section{Limitations in miRNA Biomarker Studies}

Nevertheless, although studies on the development of miRNAs as biomarkers are blooming, several limitations should be addressed. One of the main limitations is poor consensus between different studies on a particular disease. This may be due to a lack of standardization in the choice of control population, source of circulating miRNAs (serum/plasma/ urine/saliva/etc), isolation protocol (Teng et al., 2017; Wang et al., 2017), choice of internal and exogenous control (Fornari et al., 2015; Ostenfeld et al., 2016; Yuan et al., 2016; Khare et al., 2017; Rabinowits et al., 2017), analytical approach (e.g., using microarray versus RT-qPCR), or sample size (Niculescu et al., 2015). The source of miRNAs being the cause of variation in results can be seen in a study reported by Huang et al. (2017; tissues versus circulating miRNAs) and a study by Reithmair et al. (2017; cellular versus vesicle or cell-free miRNAs). The second limitation is lacking a large sample size and validation of results in different independent cohorts (Gallo et al., 2012; Momen-Heravi et al., 2015; Dinh et al., 2016; Jansen et al., 2016; Beg et al., 2017; Huang et al., 2017; Khare et al., 2017; Liu et al., 2017a; Rabinowits et al., 2017; Yokoi et al., 2017). The sample size in biomarker studies is usually only suitable for a pilot study. The third limitation is a lack of detailed study of a particular disease. Limitations in financing, facilities, and sample sources can lead to an inability to perform all related experiments on a particular disease in order to reach a conclusive result. Hence, there is still a huge amount of room for uncertainty over whether the published results (Jansen et al., 2016) show the reality of the disease condition. The fourth limitation is the effect of external factors such as age, gender, the matched control, and other external factors (tobacco, alcohol, etc.); these are usually neglected, but they may contribute to variation in results (Rabinowits et al., 2017). Rani (2017) reported such a case, where hsa-let-7e-5p and hsa-miR-103a-3p expression were decreased while the expression of other miRNAs was elevated in either the blood or plasma of Alzheimer's patients. This situation emphasizes the importance of considering age when investigating biomarkers for a disease (Rani et al., 2017). The fifth limitation is an inability to specifically pinpoint the origin of the miRNAs. Most of the studies considering circulating miRNAs as biomarkers focused on using blood as the miRNA source. However, human blood contains a variety of cell types, hence making it challenging to identify the cell origin of the particular miRNA focused on in a study (Endzeliņš et al., 2017; Murray et al., 2017).

\section{EXTRACELLULAR VESICLES (EVS)}

Extracellular vesicles (EVs), which are produced by cells, can be divided into three main types according to their size and biogenesis: exosomes, microvesicles (MVs), and apoptotic bodies (refer to Table 5 for distinctions between exosomes and other EVs). Previous studies have shown that EVs can be

TABLE 5 | Distinctions between exosomes, microvesicles (MVs)/microparticles (MPs), and apoptotic bodies.

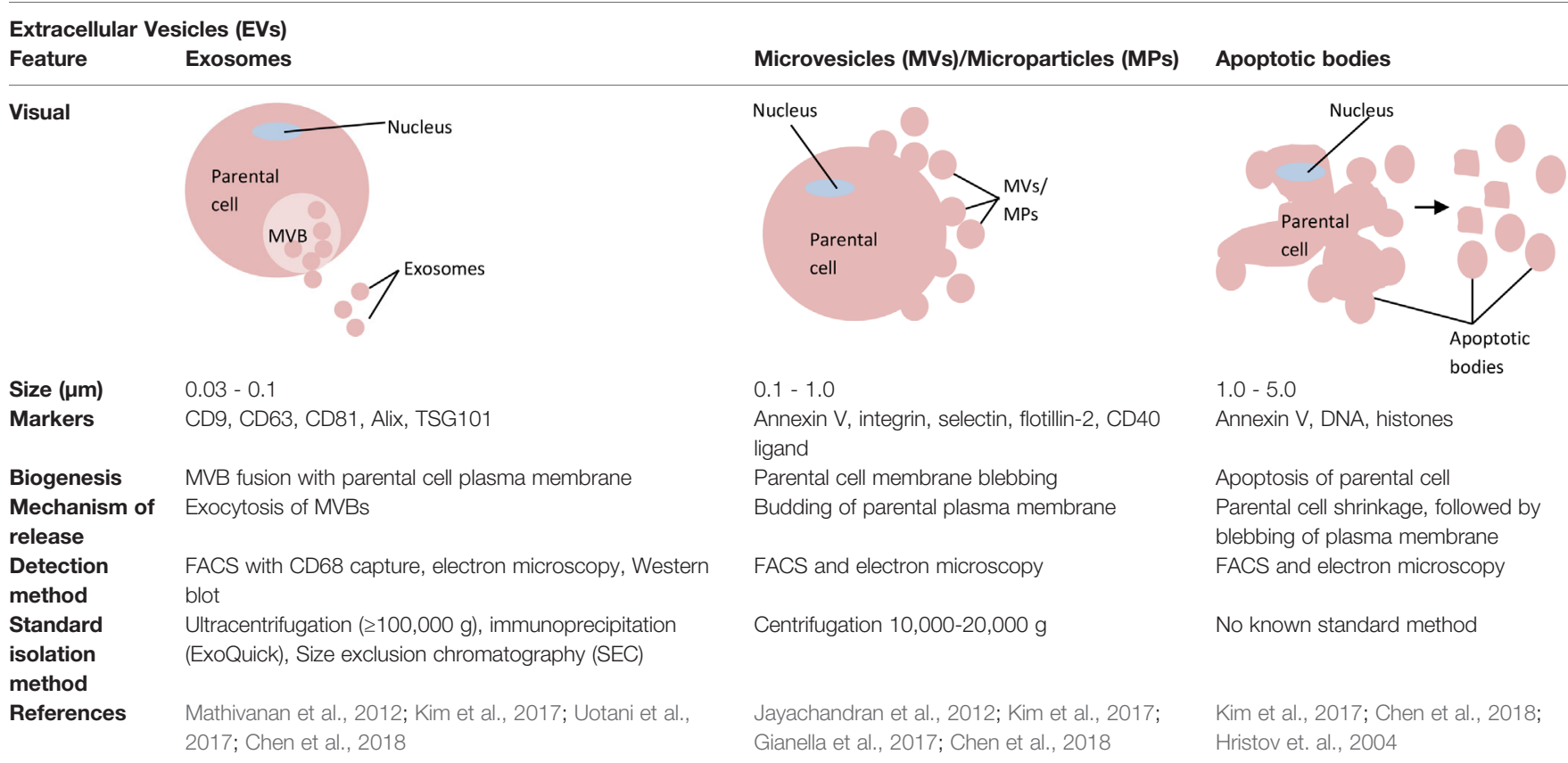


secreted by a variety of cell types and can be isolated from different sources such as blood, urine, breast milk, and saliva. EVs contain different types of molecules, such as DNA, RNA, miRNA, lipids, and proteins. EV membranes are known to protect their contents, for example, from degradation activities by nucleases and proteases and also from micro-environment changes (such as fluctuations in $\mathrm{pH}$ and osmolarity). EV contents can be transported from the origin parental cells to a specific recipient cell, either via horizontal transfer or via distant tissues. The easy accessibility of EVs for isolation, their stability, and the ability of their contents to be transported from cell to cell make EVs attractive sources for diagnostic and prognostic biomarkers (Kim et al., 2017).

Based on the current state of knowledge, there are four potential modes for loading miRNAs into extracellular vesicles (EVs), especially in exosomes, although the underlying mechanisms remain largely unclear (Figure 2). The first potential mode is via ceramide pathways (Kosaka et al., 2010; Vickers and Remaley, 2012; O'Brien et al., 2018), which are also known as neutral sphingomyelinase 2 (nSMase2)-dependent pathways (Kosaka et al., 2013; Zhang et al., 2015). Sphingolipid ceramide is known to facilitate the process from endosomal vesicle formation to the transportation of miRNAs into exosomes. This ceramide is produced by hydrolysis of sphingomyelin using neutral sphingomyelinases such as nSMase2. Quantitative studies on exosomal miRNAs have shown that the quantity of exosomal miRNAs is directly proportional to the quantity of nSMase2. As such, nSMase2 inhibition by GW4869 resulted in a reduction of exosomes and exosomal-miRNA export. Conversely, an increase in nSMase2 has been shown to increase the number of exosomal miRNAs (Trajkovic et al., 2008; Kosaka et al., 2010; Vickers and Remaley, 2012; Kosaka et al., 2013). The second potential mode is via a specific miRNA motif and the sumoylated heterogeneous nuclear ribonucleoprotein (hnRNP)-dependent pathway

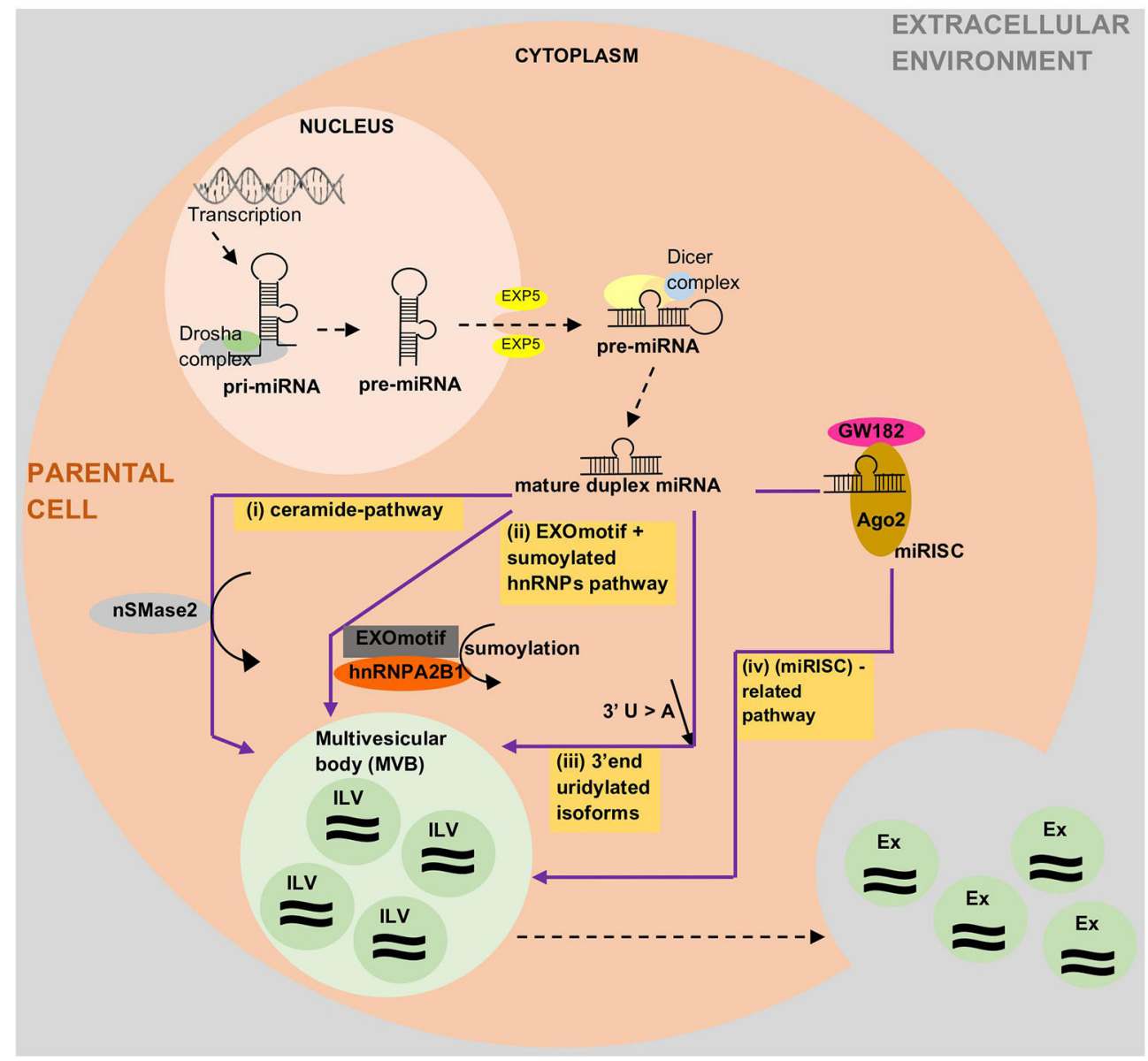

FIGURE 2 | Current state of knowledge on how miRNAs are loaded into exosomes and other extracellular vesicles (EVs). The proposed mechanisms are via (i) ceramide pathways, (ii) recognition of EXOmotifs and the sumoylated heterogenous nuclear ribonucleoproteins (hnRNPs)-dependent pathway, (iii) uridylated 3 'end isoforms, or (iv) the miRNA-induced silencing complex (miRISC)-related pathway. Ago2, Argonaute-2; Ex, Exosome; EXOmotif, short sequence motifs in miRNAs; EXP5, exportin-5; hnRNPA2B1, heterogenous nuclear ribonucleoprotein A2B1; ILV, intraluminal vesicle; miRISC, miRNA induced silencing complex; nSMase2, neutral sphingomyelinase 2 . 
(Villarroya-Beltri et al., 2013; Zhang et al., 2015; Kim et al., 2017). A study by Villarroya et al. showed two important things that can control the loading of miRNAs into exosomes, namely the short sequence motifs in miRNAs (EXOmotifs) and sumoylation of heterogeneous nuclear ribonucleoprotein A2B1 (hnRNPA2B1). EXOmotifs help hnRNPA2B1 to recognize and bind to specific miRNAs, while sumoylation controls the rate of this binding. Hence, the mutagenesis of EXOmotifs and changes in sumoylated hnRNPA2B1 expression level can affect the loading rate of miRNAs into exosomes. This finding is supported by previous studies that showed the ability of short sequences to guide the transport of RNAs to different subcellular compartments; for example, (1) 20-nucleotide stem-loop sequence was able to direct nuclear-encoded mRNA into mitochondria (Wang et al., 2010), and (2) the hexanucleotide terminal motif of miR-29b was able to direct nuclear enrichment of this miRNA (Hwang et al., 2007; Villarroya-Beltri et al., 2013). The third potential mode is via the 3'-end miRNA sequence-dependent pathway (Koppers-Lalic et al., 2014; Zhang et al., 2015). Koppers-Lalic et al. performed a comparison between the $3^{\prime}$ end of miRNAs in exosomes and the $3^{\prime}$ end of miRNAs in parental cells (B cells). The profiles from RNA sequencing (RNA-seq) showed that 3 '-end adenylated miRNAs dominated the parental cells, whereas 3 '-end uridylated isoforms dominated the exosomes. A validation study using urine samples confirmed the findings. This suggests that the $3^{\prime}$-end miRNA sequence might play a role in sorting miRNAs into exosomes (Koppers-Lalic et al., 2014). The last potential mode is via the miRNA-induced silencing complex (miRISC)-related pathway (Gibbings et al., 2009; Frank et al., 2010; Zhang et al., 2015 and Lee et al., 2009). Mature miRNA can interact with assembly proteins to form a complex called miRISC. miRISC consists of miRNA, miRNA-repressible mRNA, GW182, and AGO2 (Argonaute-2 protein: miRNA effector protein). Any changes in one of the miRISC components may affect the loading of miRNAs into EVs. For example, a crystal structure study on a eukaryotic AGO human protein, AGO2, showed the presence of a middle (MID) domain in the protein. This domain was shown to mediate interaction preferably with adenine (A) and uracil (U) at the phosphorylated 5 '-end miRNAs. Thus, these miRNAs will probably be found be to enriched in EVs compared to in miRNAs without U or A at their 5' end (Frank et al., 2010). Other findings supporting the role of miRISC in miRNA sorting into exosomes: (1) the main component of miRISC, GW182, was found to be co-localized in multivesicular bodies (MVBs) and exosomes (Gibbings et al., 2009), (2) blockage of the turnover of MVBs into lysosomes (due to loss of Hermansky-Pudlák Syndrome 4 [HPS4]) could lead to over-accumulation of miRISC and blockage of MVB formation (due to loss of endosomal sorting complex required for transport [ESCRT]), resulting in loss of miRISCs (Lee et al., 2009), and (3) changes in miRNA-repressible target levels caused by cell activation, which leads to sorting of miRNAs into exosomes.

\section{Description of Exosomes}

Exosomes were first discovered by Pan and Johnstone in 1983 during their sheep reticulocyte-related experiment. They termed them 'a type of small vesicles' responsible for the transportation of receptors into extracellular space during the maturation of sheep reticulocytes (Pan and Johnstone, 1983). Later, Johnstone et al. described these small vesicles visually, using transmission microscopy, and defined the vesicles as exosomes (Johnstone et al., 1989). Exosomes are the smallest vesicles in the EV group, with diameters starting from $0.03 \mu \mathrm{m}$ and ranging up to $0.1 \mu \mathrm{m}$ (Chen et al., 2018) or $0.12 \mu \mathrm{m}$ (Fleissner et al., 2012). The presence of exosomes in a particular source can be confirmed by either: (i) observation of a cup-shaped morphology under negative-staining transmission microscopy or (ii) the presence of exosome markers such as CD63, CD9, and CD81 (Simons and Raposo, 2009; Mathivanan et al., 2010; Gross et al., 2012). Exosomes contain various types of molecules, such as lipids, proteins, lipid rafts, mRNAs, miRNAs, and other non-coding RNAs, such as long non-coding RNAs (lncRNAs) (Zhang et al., 2015). Various cell types can release exosomes, such as reticulocytes (Pan and Johnstone, 1983; Diaz-Varela et al., 2018), dendritic cells (Morelli et al., 2004; Huang et al., 2019), B cells (Benjamin et al., 2019), mast cells (Xie et al., 2018), T cells (Wang et al., 2019), epithelial cells (Lv et al., 2019), and tumor cells (McAtee et al., 2019).

Exosomes are small intraluminal vesicles derived from the exocytosis of multivesicular bodies (MVBs) with plasma membrane (Kosaka et al., 2010; Kim et al., 2017). Specifically, the biogenesis of exosomes starts with the internalization of parental cell membrane to produce endosomes. Small vesicles are formed inside endosomes by invaginating parts of the endosome membranes. These endosomes with small vesicles inside them are called multivesicular bodies (MVBs). MVBs or late endosomes later fuse with parental cell membrane to release the intraluminal endosomal vesicles into the extracellular environment to become exosomes (Zhang et al., 2015). Several molecules have been reported to play crucial roles in the release of exosomes. For example, knockdown of molecules such as Rab27a, Rab27b, or their effectors, SYTL4 and EXPN5, has been shown to result in inhibition of exosome secretion (Ostrowski et al., 2010). Meanwhile, molecules such as tumor repressor protein $\mathrm{p} 53$ and its downstream effector, TSAP6, can enhance exosome production (Yu et al., 2006). In addition, the syndecansyntenin molecule was shown to support the intraluminal budding of endosomal membranes (a crucial step in exosome development) by directly interacting with the ALIX protein (Baietti et al., 2012).

Using exosomes as the source for biomarker development might have several advantages when compared to other existing strategies. The exosome contents reflect the status of parental cells (Momen-Heravi et al., 2015; Pirola et al., 2015; Sohn et al., 2015; Uratani et al., 2016; Liu et al., 2017a; Wang et al., 2017; Yan et al., 2017). Exosomes are also specific (in terms of type and concentration) (Chen et al., 2017; Ebrahimkhani et al., 2017; Perge et al., 2017), which means that they can reflect an individual's health status (Cazzoli et al., 2013). This specificity enables the analysis of low-abundance molecules of interest in a less complex environment (Momen-Heravi et al., 2015; Ramachandran et al., 2017). Exosomes act as a cargo, 
transferring their biologically active components (Liu et al., 2017a) into targeted cells, playing the role of a cell-to-cell communicator (Pirola et al., 2015; Dinh et al., 2016; Emanueli et al., 2016; Uratani et al., 2016; Weilner et al., 2016; Ramachandran et al., 2017; Fu et al., 2018).

According to the idea that exosomal miRNAs are the best source compared to non-exosomal, cell-free, or whole unfractionated samples, we summarize the selected studies that focus on biomarker findings where the sole source is exosomes in Table 2.

\section{Description of Other EVs Microvesicles (MVs)/ Microparticles (MPs)}

Apart from exosomes, the other type of EVs that is recorded by this review analysis as a potential source for circulating miRNAs is microvesicles (MVs)/microparticles (MPs). MVs/MPs range in size from 0.1 to $1 \mu \mathrm{m}$ in diameter (Chen et al., 2018). These vesicles contain a fraction of the plasma membrane of the parental cells from which the vesicles budded (Kim et al., 2017). Specifically, MVs/MPs are produced via direct outward blebbing of parental cell plasma membranes, releasing nascent vesicles into the extracellular environment. Following the blebbing of membrane, distinct and localized changes will occur in the protein and lipid components of the plasma membrane, leading to changes in membrane curvature and rigidity. Proteins that are identified to have functional roles in $\mathrm{MV} / \mathrm{MP}$ biogenesis are: aminophospholipid translocases (flippasae and floppases) (Stachowiak et al., 2013), ADPribosylation factor 1 (ARF1: activation of contractile machinery via myosin light chain kinase [MLCK]) (Schlienger et al., 2014), ARF6 (regulates the selective recruitment of proteins into $\mathrm{MVs} / \mathrm{MPs}$ and activates contractile machinery via MLCK) (Muralidharan-Chari et al., 2009), arrestin domain containing 1 (ARRDC1), Tumor susceptibility gene 101 (TSG101) (Nabhan et al., 2012), diaphanous related formin 3 (DIAPH3) (Kim et al., 2014), glutaminase (Li et al., 2012), Hyaluranon synthase (Rilla et al., 2013), localized protein enrichment (Stachowiak et al., 2012), myosin-1a (McConnell et al., 2009), Rab22a (selective recruitment of proteins to MVs/MPs under hypoxic conditions (Wang et al., 2014), and RhoA (links ARF6 activation to MLS phophorylation via the ROCK signaling pathway and is involved in actin cytoskeleton rearrangements via the RhoA-cofin pathway; Li et al., 2012; Schlienger et al., 2014; Sedgwick et al., 2015). Changes in the above components are complemented by a vertical redistribution of MV/MP cargo components, which are selectively enriched within MVs/MPs (Tricarico et al., 2017).

MVs/MPs can be found in blood circulation (Lacroix et al., 2013; Giannella et al., 2017) as well as other body fluids, such as urine (Smalley et al., 2008), as a result of the activation of cell membrane and/or apoptosis processes (Jesel et al., 2013). MVs/ MPs can be shed form various types of cells, such as leukocytes (Pieper et al., 2018), erythrocytes (Yuan et al., 2018), platelets (Diehl et al., 2012; Maugeri et al., 2018), or endothelial cells (Giannella et al., 2017; Zhang et al., 2017). The shed MVs/MPs may or may not contain receptors of their parental cells (Mause et al., 2010; Morel et al., 2011). MVs/MPs are known to participate in biological activities associated with inflammation, immune responses, and thrombosis (Goubran et al., 2015). The intracellular communication of MVs/MPs with targeted cells can be either via (1) direct interaction with ligands presented on the surface of targeted cells, (ii) binding of MVs/MPs to the membrane of targeted cells (requires a specific surface antigen), (iii) indirect interaction through modulation of the extracellular environment, or (iv) internalization-fusion to influence gene regulation (Dengler et al., 2013; Goubran et al., 2015; Markiewicz et al., 2013; Mause et al., 2010).

MVs/MPs can be isolated by centrifugation within the range of 13,000 (Zhang et al., 2017) to 20,000 (Jansen et al., 2016) gforce, which can be done without a need for specialized ultracentrifugation machinery. Although this factor seems advantageous toward MVs/MPs as compared to exosomes, the literature shows the opposite, with more studies focusing exosomes than on MVs/MPs. Perhaps, the availability of extensive information regarding exosomes contributes to this phenomenon. Only four studies selected in this review (Diehl et al., 2012; Jansen et al., 2016; Giannella et al., 2017; Zhang et al., 2017) focused solely on MVs/MPs (Table 2).

\section{Apoptotic Bodies}

Apoptotic bodies are the largest vesicles in the EV group, with a diameter range of 1 to $5 \mu \mathrm{m}$ (Chen et al., 2018). In contrast to exosomes or MVs/MPs, apoptotic bodies are formed only during programmed cell death. The biogenesis of apoptotic bodies starts from apoptosis. A cell that undergoes apoptosis will first experience nuclear chromatin condensation, followed by membrane blebbing and, lastly, the disintegration of cellular components into distinct membranes enclosing vesicles in the apoptotic bodies. Usually, the apoptotic bodies produced will be phagocytosed by macrophages and cleared locally. This clearance process is mediated by interactions between recognition receptors (Annexin V) present on phagocytes with components of the membrane of the apoptotic bodies [phosphatidylserine translocates to the outer leaflet of the lipid bilayer for the interaction (Martinez and Freyssinet, 2001)]. On the other hand, oxidation of surface molecules of apoptotic bodies creates sites for binding of thrombospondin (Savill, 1997; Friedl et al., 2002) or the complement protein C3b (Takizawa et al., 1996). This thrombospondin or $\mathrm{C} 3 \mathrm{~b}$ can then be recognized by phagocyte receptors (Erwig and Henson, 2008; Mevorach et al., 1998). Hence, Annexin $\mathrm{V}$, thrombospondin, and $\mathrm{C} 3 \mathrm{~b}$ are used as markers for apoptotic body studies (Savill et al., 1992; Akers et al., 2013).

\section{NON-EXOSOMAL: SOURCES OTHER THAN EVS (HDL-COMPLEXES AND AGO2- COMPLEXES)}

According to the analysis carried out for this review, the source of non-exosomal miRNAs can be either microvesicles (MVs)/ microparticles (MPs), as described in the Extracellular Vesicles (EVs) section or from a protein-miRNA complex (such as high- 
density lipoprotein [HDL] or Argonaute protein [Ago2]) (Redis et al., 2012). In this section, the HDL and Ago2 sources are described.

In general, very few articles report miRNA biomarker studies using solely a non-exosomal source. Only six such articles were successfully retrieved via our search strategy, four of which used only microparticles (MPs) miRNAs and two of which used HDLmiRNAs complexes. We summarize the findings in Table 1.

\section{High-Density Lipoprotein (HDL)}

High-density lipoprotein (HDL) consists of proteins (75-80\%) and lipids (20-25\%). The lipids can be fractionated further into phospholipids (65\%), triglycerides (30\%), and cholesterol (5\%). As a major part of HDL is protein, the density of HDL is close to that of protein, which is 1.120 gram per milliliter (Cook and Martin, 1969). The molecular weight of HDL is about $400 \mathrm{kDa}$, and its diameter ranges from 7 to $20 \mathrm{~nm}$ (Burley and Cook, 1961). HDL is formed by a dimer of two monomers, weighing $200 \mathrm{kDa}$ each. Each of the HDL monomers is composed of about five main apoproteins, with molecular weights ranging from 35 to $110 \mathrm{kDa}$. Each monomer has a funnel-shaped cavity (with a volume of 68 $\mathrm{nm}^{3}$ ), built by 2 beta-sheets (constituted by hydrophobic acids) (Anderson et al., 1998). Each cavity is large enough to fix about 35 molecules of phospholipids concentrated on a monolayer that interact with the cavity's hydrophobic nucleic acid. This hydrophobic cavity protects molecules trapped inside it; as such, phospholipase C can only liberate $6 \%$ of the lipid phosphorus of HDLs (Burley and Kushner, 1963; Anton, 2007).

HDL formation is known to taken place in the liver and intestine. The approved biogenesis of HDL involves the interaction of lipid-poor ApoA-1 and ATP binding cassette A1 (ABCA1). $A B C A 1$ is part of the membrane transporter group, functioning as a promoter of transportation of phospholipid and cholesterol from parental cells to poorly lipidated ApoI. The binding of ApoI to ABCA1 has been shown to increase the stability and activity of the transporter in the parental plasma membrane. ATP hydrolysis leads ABCA1 to promote transbilayer transportation of phospholipids from the inner to the outer leaflet of the parental plasma membrane. This packing forms extravesiculated lipid domains. ApoI binds to this domain and promotes spontaneous solubilization, which leads to the formation of pre-beta-HDL particles (Canfra'n-Duque et al., 2014; Duong et al., 2006; Vedhachalam et al., 2007). Other proteins and enzymes that are involved in HDL maturation and remodeling include: (i) ATP-binding cassette sub-family G member 1 (ABCG1) (with ABCA1, synergistically mediates cholesterol efflux to HDL) (Gelissen et al., 2006), (ii) scavenger receptor class B type 1 (SRB1) (mediates cholesterol bidirectional flux from cells and HDL, which modulates changes in the composition and structure of HDL particles) (Ji et al., 1997; Jian et al., 1998), (iii) lecithin-cholesterol acyltransferase (LCAT) (mediates fatty acid transportation to pre-beta-HDL to form cholesteryl ester) (Jonas, 1991; Fielding et al., 1972), (iv) cholesteryl ester transfer protein (CETP) (an enzyme that helps in the transportation of both cholesteryl ester and trigylcerides between lipoproteins) (Tall, 1993; Fielding and Fielding, 1995), (v) phospholipid transfer protein (PLTP) (mediates phospholipid transportation from ApoB-containing lipoproteins to HDL), and both (vi) hepatic lipase (HL) and (vii) endothelial lipase (EL) (participate in HDL metabolism) (Connelly, 1999).

Recently, HDL has been reported to act as a transporter in delivering miRNAs to recipient cells, and miRNAs have been proven to influence the gene expression in the recipient cell. For example, in a study where the most abundant miRNA transported by HDL, miR-223 (up to 10,000 copies per microgram of $\mathrm{HDL}$ ), was transported to Huh7 cells showed a significant reduction of miR-223 target gene expression (Vickers et al., 2011). In addition to that, in this review, two studies (Niculescu et al., 2015; Tabet et al., 2016) involving human samples also shown evidence for miRNA transportation via HDL.

Other than miRNAs, HDL is also reported to act as a carrier of fat-soluble vitamins [such as vitamin E (Sattler et al., 1996) and vitamin D (Vaisar et al., 2007; Alwaili et al., 2012)], steroids (lipophilic thyroid hormone thyroxine [T4]; Benvenga et al., 1989), hormones (estrogen, pregnenolone and dehydroepiandrosterone; Tikkanen, et al., 2002), and carotenoids (lycopene, lutein; Krinsky et al., 2004; Vickers and Remaley, 2013).

\section{Argonaute Protein (Ago2)}

The term 'Argonaute' for proteins comes from the findings of the Bohmert group. The group described a mutant protein in Arabidopsis thaliana as AGO1 (Argonaute-1) because the leaf morphology of this plant resembles the shape of a small squid named the 'greater Argonaut' or Argonauta argo (Bohmert et al., 1998). Argonaute proteins can be classified into three paralogous groups, which are: (i) Argonaute-like proteins (resembling Arabidopsis thaliana AGO1) (Bohmert et al., 1998), (ii) Piwilike proteins (closely related to Drosophila melanogaster PIWI [P-element induced wimpy testis]) (Lin and Spradling, 1997), and (iii) the Caenorhabditis elegans-specific group 3 Argonautes (Yigit et al., 2006).

There are four domains in an Argonaute protein, namely the N-terminal, PAZ (Piwi-Argonaute-Zwille), Mid (Middle), and PIWI (Parker et al., 2005). The N-terminal domain is involved in (i) the loading of small RNAs to the protein, (ii) assisting in the unwinding process of small RNA duplexes (Kwak and Tomari, 2012), and (ii) together with the PIWI domain, its unstructured loop is plays an important role in the cleavage process (Hauptmann et al., 2013). The PAZ domain is responsible for recognizing the 3 '-overhangs of small RNAs and leads the small RNAs into a specific binding pocket inside the protein (Jinek and Doudna, 2009). The MID domain provides a binding pocket at which the 5'-terminal bases of small RNAs can form stacking interactions with a conserved tyrosine within it. In addition, several hydrogen bonds help to coordinate correct 5 -end binding. The PIWI domain is responsible for endonucleases, which cleave target RNA that is fully complementary to the bound small RNA (Jinek and Doudna, 2009). However, not all Argonaute proteins possess cleavage activity. For example, in mammals, only AGO2 of the AGO subfamily is catalytically active and functioning as an endonuclease (Liu et al., 2004; Meister et al., 2004). 
Apart from being a cleavage location for bound miRNA target genes, Argonaute proteins also play a role as miRNA carriers. This carrier role has been demonstrated in several articles that have been analyzed in this review, for example: (i) Arroyo et al. found that $90 \%$ of miRNAs in circulation (from human plasma samples) were present in a non-membrane-bound form consistent with a ribonucleoprotein complex (Ago2 ribonucleoprotein complex) and that this complex provides stability for nonvesicular circulating miRNAs (Arroyo et al., 2011); (ii) the Turchinovich et al. study showed similar results to that of Arroyo et al.; that is, that the majority of nuclease-resistant extracellular miRNAs in both plasma and cell culture media is floating outside exosomes and is bound to the Ago 2 protein (Turchinovich et al., 2011).

\section{PERFORMANCE COMPARISON OF EXOSOMAL AND NON-EXOSOMAL CIRCULATING MIRNAS AS POTENTIAL BIOMARKERS}

Tables 3 and 4 summarize the articles on the role and mechanism of circulating miRNAs and their potential to be used as biomarkers. Out of the total of 69 articles cited, six were exclusively on non-exosomes, 31 were exclusively on exosomes, and the remaining 32 related to both exosomes and nonexosomes. Out of these 32, 18 articles pointed to exosomal miRNAs, six to non-exosomal miRNAs, and 7 to unfractionated samples as a better source for miRNAs used as a biomarker. However, one article differed from the above, stating that similar expression was observed both in whole and exosomal serum samples (Figure 1).

Based on the above data, it is obvious that $71 \%$ of the articles $(31+18)$ concluded that exosomes are the source of choice for miRNAs in biomarker studies. Moreover, taking into consideration the articles (18) that compared both exosomal and non-exosomal miRNAs, 75\% recommended an exosomal source of miRNAs over non-exosomal miRNAs. Though the debate on the preference and recommendation of the source of miRNAs, whether exosomal or non-exosomal, is never-ending, summing up the information based on the literature, it can be inferred that the

\section{REFERENCES}

Akers, J. C., Gonda, D., Kim, R., Carter, B. S., and Chen, C. C. (2013). Biogenesis of extracellular vesicles (EV): exosomes, microvesicles, retrovirus-like vesicles, and apoptotic bodies. J. Neurooncol. 113, 1-11. doi: 10.1007/s11060-013-1084-8

Alhasan, A. H., Scott, A. W., Wu, J. J., Feng, G., Meeks, J. J., Thaxton, C. S., et al. (2016). Circulating microRNA signature for the diagnosis of very high-risk prostate cancer. Proc. Natl. Acad. Sci. U.S.A. 113, 10655-10660. doi: 10.1073/ pnas. 1611596113

Alwaili, K., Bailey, D., Awan, Z., Bailey, S. D., Ruel, I., Hafiane, A., et al. (2012). The HDL proteome in acute coronary syndromes shifts to an inflammatory profile. Biochim. Biophys. Acta Mol. Cell Biol. Lipids 1821, 405-415. doi: 10.1016/ j.bbalip.2011.07.013 exosomal source of miRNAs can act as a better source for biomarker studies owing to its advantages in terms of quantity, quality, and stability. Hence, the exosomal source of miRNAs holds promise in studies related to biomarkers and diseases, which can be reaped for the benefit of mankind in terms of screening and surveillance. Having said that, the role of other biomarkers for disease diagnosis from other sources cannot be ignored altogether. Further exploration is needed to ascertain how other biomarkers can be used hand-in-hand with miRNAs from exosomal sources; these may complement each other and make disease diagnosis more efficient and timely. This hence warrants further research, exploring other possible resources that can be reaped for early diagnosis, prevention, and treatment of diseases.

\section{SIGNIFICANCE STATEMENT}

This review was written with the aim to compare all studies pertaining to circulatory miRNA and to evaluate the validity of using exosomal or non-exosomal as biomarker in diseases.

\section{AUTHOR CONTRIBUTIONS}

NN and WS wrote or contributed to the writing of the manuscript.

\section{FUNDING}

This review is part of research funded by the Fundamental Research Grant Scheme (FRGS), Malaysia [Grant number: FRGS/1/2016/203.PPSG. 6171194].

\section{ACKNOWLEDGMENTS}

We thank the Ministry of Higher Education, Malaysia, for providing the Fundamental Research Grant Scheme (FRGS), which enabled the conduct of the research related to this review.

Anderson, T. A., Levitt, D. G., and Banaszak, L. J. (1998). The structural basis of lipid interactions in lipovitellin, a soluble lipoprotein. Structure 6, 895-909. doi: 10.1016/S0969-2126(98)00091-4

Anton, M. (2007). "High-density lipoproteins (HDL) or lipovitellin fraction," in Bioactive Egg Compounds (Berlin, Heidelberg: Springer), 13-16. doi: 10.1007/ 978-3-540-37885-3_3

Arroyo, J. D., Chevillet, J. R., Kroh, E. M., Ruf, I. K., Pritchard, C. C., Gibson, D. F., et al. (2011). Argonaute 2 complexes carry a population of circulating microRNAs independent of vesicles in human plasma. Proc. Natl. Acad. Sci. U.S.A. 108, 5003-5008. doi: 10.1073/pnas.1019055108

Baietti, M. F., Zhang, Z., Mortier, E., Melchior, A., Degeest, G., Geeraerts, A., et al. (2012). Syndecan-syntenin-ALIX regulates the biogenesis of exosomes. Nat. Cell Biol. 14, 677. doi: 10.1038/ncb2502 
Beg, F., Wang, R., Saeed, Z., Devaraj, S., Masoor, K., and Nakshatri, H. (2017). Inflammation- associated microRNA changes in circulating exosomes of heart failure patients. BMC Res. Notes 10, 751. doi: 10.1186/s13104-017-3090-y

Benjamins, J. A., Nedelkoska, L., Touil, H., Stemmer, P. M., Carruthers, N. J., Jena, B. P., et al. (2019). Exosome-enriched fractions from MS B cells induce oligodendrocyte death. Neurol. Neuroimmunol. Neuroinflamm. 6, e550. doi: 10.1212/NXI.0000000000000550

Benvenga, S., Cahnmann, H. J., Gregg, R. E., and Robbins, J. (1989). Characterization of the binding of thyroxine to high density lipoproteins and apolipoproteins AI. J. Clin. Endocrinol. Metab. 68, 1067-1072. doi: 10.1210/ jcem-68-6-1067

Bohmert, K., Camus, I., Bellini, C., Bouchez, D., Caboche, M., and Benning, C. (1998). AGO1 defines a novel locus of Arabidopsis controlling leaf development. $Е M B O$ J. 17, 170-180. doi: 10.1093/emboj/17.1.170

Burley, R. W., and Cook, W. H. (1961). Isolation and composition of avian egg yolk granules and their constituent $\alpha$-and $\beta$-lipovitellins. Can. J. Biochem. Physiol. 39, 1295-1307. doi: 10.1139/o61-136

Burley, R. W., and Kushner, D. J. (1963). The action of Clostridium perfringens phosphatidase on the lipovitellins and other egg yolk constituents. Can. J. Biochem. Physiol. 41, 409-416. doi: 10.1139/063-049

Canfran-Duque, A., Ramírez, C. M., Goedeke, L., Lin, C. S., and FernandezHernando, C. (2014). microRNAs and HDL life cycle. Cardiovasc. Res. 103, 414-422. doi: 10.1093/cvr/cvu140

Cazzoli, R., Buttitta, F., Di Nicola, M., Malatesta, S., Marchetti, A., Rom, W. N., et al. (2013). microRNAs derived from circulating exosomes as noninvasive biomarkers for screening and diagnosing lung cancer. J. Thorac. Oncol. 8, 1156-1162. doi: 10.1097/JTO.0b013e318299ac32

Chen, Y., Song, Y., Huang, J., Qu, M., Zhang, Y., Geng, J., et al. (2017). Increased circulating exosomal miRNA-223 is associated with acute ischemic stroke. Front. Neurol. 8, 57. doi: 10.3389/fneur.2017.00057

Chen, Y., Li, G., and Liu, M. L. (2018). Microvesicles as emerging biomarkers and therapeutic targets in cardiometabolic diseases. Genomics Proteomics Bioinf. 16, 50-62. doi: 10.1016/j.gpb.2017.03.006

Chugh, P. E., Sin, S. H., Ozgur, S., Henry, D. H., Menezes, P., Griffith, J., et al. (2013). Systemically circulating viral and tumor-derived microRNAs in KSHVassociated malignancies. PloS Pathol. 9, e1003484. doi: 10.1371/ journal.ppat.1003484

Cook, W. H., and Martin, W. G. (1969). "Egg lipoproteins" in: structural and functional aspects of lipoproteins in living systems, eds. E. Tria and A. M. Scanu (London: Academic Press), 579-615.

Connelly, P. W. (1999). The role of hepatic lipase in lipoprotein metabolism. Clin. Chim. Acta 286, 243-255. doi: 10.1016/S0009-8981(99)00105-9

Crossland, R. E., Norden, J., Kralj Juric, M., Pearce, K. F., Lendrem, C., Bibby, L. A., et al. (2017). Serum and extracellular vesicle microRNAs miR-423, miR-199, and miR-93* as biomarkers for acute graft-versus-host disease. Front. Immuno. 8, 1446. doi: 10.3389/fimmu.2017.01446

Dardari, R. K., Khyatti, M., Benider, A., Jouhadi, H., Kahlain, A., Cochet, C., et al. (2000). Antibodies to the Epstein-Barr virus transactivator protein (ZEBRA) as a valuable biomarker in young patients with nasopharyngeal carcinoma. Inter. J. Cancer 86, 71-75. doi: 10.1002/(SICI)1097-0215(20000401)86:1<71::AIDIJC11>3.0.CO;2-1

de Candia, P., Torri, A., Gorletta, T., Fedeli, M., Bulgheroni, E., Cheroni, C., et al. (2013). Intracellular modulation, extracellular disposal and serum increase of MiR-150 mark lymphocyte activation. PloS ONE 8, p. e75348. doi: 10.1371/ journal.pone. 0075348

de Gonzalo-Calvo, D., Van Der Meer, R. W., Rijzewijk, L. J., Smit, J. W. A., Revuelta-Lopez, E., Nasarre, L., et al. (2017). Serum microRNA-1 and microRNA-133a levels reflect myocardial steatosis in uncomplicated type 2 diabetes. Sci. Rep. 7, 47. doi: 10.1038/s41598-017-00070-6

Dengler, E. C., Liu, J., Kerwin, A., Torres, S., Olcott, C. M., Bowman, B. N., et al. (2013). Mesoporous silica-supported lipid bilayers (protocells) for DNA cargo delivery to the spinal cord. J. Control Release 168, 209-224. doi: 10.1016/ j.jconrel.2013.03.009

Diaz-Varela, M., Gualdrón-López, M., de Menezes-Neto, A., Perez-Zsolt, D., Gámez-Valero, A., Segui-Barber, J., et al. (2018). Development of human reticulocyte-derived exosomes as a new vaccine delivery platform against Plasmodium vivax malaria. J. Extracell Vesciles 7, 189-190.
Diehl, P., Fricke, A., Sander, L., Stamm, J., Bassler, N., Htun, N., et al. (2012). Microparticles: major transport vehicles for distinct microRNAs in circulation. Cardiovas. Res. 93, 633-644. doi: 10.1093/cvr/cvs007

Dinh, T. K. T., Fendler, W., Chałubińska-Fendler, J., Acharya, S. S., O'Leary, C., Deraska, P. V., et al. (2016). Circulating miR-29a and miR- 150 correlate with delivered dose during thoracic radiation therapy for non-small cell lung cancer. Radiat. Oncol. 11, 61. doi: 10.1186/s13014-016-0636-4

Domańska-Senderowska, D., Jastrzębski, Z., Kiszałkiewicz, J., Brzeziański, M., Pastuszak- Lewandoska, D., Radzimińki, $€$, et al. (2017). Expression analysis of selected classes of circulating exosomal miRNAs in soccer players as an indicator of adaptation to physical activity. Biol. Sport 34, 331-338. doi: 10.5114/biolsport.2017.69820

Duong, P. T., Collins, H. L., Nickel, M., Lund-Katz, S., Rothblat, G. H., and Phillips, M. C. (2006). Characterization of nascent HDL particles and microparticles formed by ABCA1-mediated efflux of cellular lipids to apoAI. J. Lipid Res. 47, 832-843. doi: 10.1194/jlr.M500531-JLR200

Duttagupta, R., Jiang, R., Gollub, J., Getts, R. C., and Jones, K. W. (2011). Impact of cellular miRNAs on circulating miRNA biomarker signatures. PloS One 6, e20769. doi: 10.1371/journal.pone.0020769

Ebrahimkhani, S., Vafaee, F., Young, P. E., Hur, S. S., Hawke, S., Devenney, E., et al. (2017). Exosomal microRNA signatures in multiple sclerosis reflect disease status. Sci. Rep. 7, 14293. doi: 10.1038/s41598-017-14301-3

Eichelser, C., Stückrath, I., Müller, V., Milde-Langosch, K., Wikman, H., Pantel, K., et al. (2014). Increased serum levels of circulating exosomal microRNA- 373 in receptor-negative breast cancer patients. Oncotarget 5, 9650-9663. doi: 10.18632/oncotarget.2520

Emanueli, C., Shearn, A. I., Laftah, A., Fiorentino, F., Reeves, B. C., Beltrami, C., et al. (2016). Coronary artery- bypass-graft surgery increases the plasma concentration of exosomes carrying a cargo of cardiac microRNAs: an example of exosome trafficking out of the human heart with potential for cardiac biomarker discovery. PloS One 11, e0154274. doi: 10.1371/ journal.pone.0154274

Endzeliņ̌s, E., Berger, A., Melne, V., Bajo-Santos, C., Soboḷevska, K., Ābols, A., et al. (2017). Detection of circulating miRNAs: comparative analysis of extracellular vesicle-incorporated miRNAs and cell-free miRNAs in whole plasma of prostate cancer patients. BMC Cancer 17, 730. doi: 10.1186/s12885017-3737-z

Erwig, L. P., and Henson, P. M. (2008). Clearance of apoptotic cells by phagocytes. Cell Death Differ. 15, 243. doi: 10.1038/sj.cdd.4402184

Fielding, C. J., and Fielding, P. E. (1995). Molecular physiology of reverse cholesterol transport. J. Lipid Res. 36, 211-228.

Fielding, C. J., Shore, V. G., and Fielding, P. E. (1972). A protein cofactor of lecithin: cholesterol acyltransferase. Biochem. Biophys. Res. Comm 46, $1493-$ 1498. doi: 10.1016/0006-291X(72)90776-0

Fleissner, F., Goerzig, Y., Haverich, A., and Thum, T. (2012). Microvesicles as novel biomarkers and therapeutic targets in transplantation medicine. Am. J. Transplant. 12, 289-297. doi: 10.1111/j.1600-6143.2011.03790.x

Fornari, F., Ferracin, M., Trerè, D., Milazzo, M., Marinelli, S., Galassi, M., et al. (2015). Circulating microRNAs, miR- 939, miR-595, miR-519d and miR-494, identify cirrhotic patients with HCC. PloS One 10, e0141448. doi: 10.1371/ journal.pone. 0141448

Frank, F., Sonenberg, N., and Nagar, B. (2010). Structural basis for 50 -nucleotide base-specific recognition of guide RNA by human AGO2. Nat 465, 818-822. doi: 10.1038/nature09039

Friedl, P., Vischer, P., and Freyberg, M. A. (2002). The role of thrombospondin-1 in apoptosis. Cell Mol. Life Sci. 59, 1347-1357 108. doi: 10.1007/s00018-002$8512-9$

Fu, F., Jiang, W., Zhou, L., and Chen, Z. (2018). Circulating exosomal miR-17-5p and miR- 92a-3p predict pathologic stage and grade of colorectal cancer. Transl. Oncol. 11, 221-232. doi: 10.1016/j.tranon.2017.12.012

Fujiwara, T., Uotani, K., Yoshida, A., Morita, T., Nezu, Y., Kobayashi, E., et al. (2017). Clinical significance of circulating miR-25-3p as a novel diagnostic and prognostic biomarker in osteosarcoma. Oncotarget 8, 33375-33392. doi: 10.18632/oncotarget.16498

Gallo, A., Tandon, M., Alevizos, I., and Illei, G. G. (2012). The majority of microRNAs detectable in serum and saliva is concentrated in exosomes. PloS One 7, e30679. doi: 10.1371/journal.pone.0030679 
Gelissen, I. C., Harris, M., Rye, K. A., Quinn, C., Brown, A. J., Kockx, M., et al. (2006). ABCA1 and ABCG1 synergize to mediate cholesterol export to apoA-I. Arter. Thromb. Vasc. Biol. 26, 534-540. doi: 10.1161/01.ATV.0000200082. 58536.e1

Giannella, A., Radu, C. M., Franco, L., Campello, E., Simioni, P., Avogaro, A., et al. (2017). Circulating levels and characterization of microparticles in patients with different degrees of glucose tolerance. Cardiovas. Diabetol. 16, 118. doi: 10.1186/s12933-017-0600-0

Gibbings, D. J., Ciaudo, C., Erhardt, M., and Voinnet, O. (2009). Multivesicular bodies associate with components of miRNA effector complexes and modulate miRNA activity. Nat. Cell Biol. 11, 1143-1149. doi: 10.1038/ncb1929

Gill, J. K., Kaur, M., Kaur, K., and Goel, S. (2017). Salivary biomarkers as a diagnostic indicator- a brief review. J. Adv. Med. Dent. Sci. Res. 5, 87-91. doi: 10.21276/jamdsr.2017.5.1.18

Goubran, H., Sabry, W., Kotb, R., Seghatchian, J., and Burnouf, T. (2015). Platelet microparticles and cancer: an intimate cross-talk. Transfus Apheresis Sci. 53, 168-172. doi: 10.1016/j.transci.2015.10.014

Gross, J. C., Chaudhary, V., Bartscherer, K., and Boutros, M. (2012). Active Wnt proteins are secreted on exosomes. Nat. Cell Biol. 14, 1036-1045. doi: 10.1038/ ncb2574

Hannafon, B. N., Trigoso, Y. D., Calloway, C. L., Zhao, Y. D., Lum, D. H., Welm, A. L., et al. (2016). Plasma exosome microRNAs are indicative of breast cancer. Breast Cancer Res. 18, 90. doi: 10.1186/s13058-016-0753-x

Hauptmann, J., Dueck, A., Harlander, S., Pfaff, J., Merkl, R., and Meister, G. (2013). Turning catalytically inactive human Argonaute proteins into active slicer enzymes. Nat. Struct. Mol. Biol. 20, 814. doi: 10.1038/nsmb.2577

Hristov, M., Erl, W., Linder, S., and Weber, P. C. (2004). Apoptotic bodies from endothelial cells enhance the number and initiate the differentiation of human endothelial progenitor cells in vitro. Blood 104, 2761-2766. doi: 10.1182/blood2003-10-3614

Huang, X., Yuan, T., Liang, M., Du, M., Xia, S., Dittmar, R., et al. (2015). Exosomal miR-1290 and miR-375 as prognostic markers in castration-resistant prostate cancer. Eur. Urol. 67, 33-41. doi: 10.1016/j.eururo.2014.07.035

Huang, Z., Zhang, L., Zhu, D., Shan, X., Zhou, X., Qi, L. W., et al. (2017). A novel serum microRNA signature to screen esophageal squamous cell carcinoma. Cancer Med. 6, 109-119. doi: 10.1002/cam4.973

Huang, L., Zhang, X., Wang, M., Chen, Z., Yan, Y., Gu, W., et al. (2019). Exosomes from thymic stromal lymphopoietin-activated dendritic cells promote Th2 differentiation through the OX40 ligand. Pathobiol 86, 111-117. doi: 10.1159/ 000493013

Hubert, A., Subra, C., Jenabian, M. A., Labrecque, P. F. T., Tremblay, C., Laffont, B., et al. (2015). Elevated abundance, size, and MicroRNA content of plasma extracellular vesicles in viremic HIV-1+ patients: correlations with known markers of disease progression. J. Acqui. Immune Defic. Syndr. 70, 219227. doi: 10.1097/QAI.0000000000000756

Hwang, H. W., Wentzel, E. A., and Mendell, J. T. (2007). A hexanucleotide element directs microRNA nuclear import. Science 315, 97-100. doi: 10.1126/ science. 1136235

Jansen, F., Yang, X., Proebsting, S., Hoelscher, M., Przybilla, D., Baumann, K., et al. (2014). MicroRNA expression in circulating microvesicles predicts cardiovascular events in patients with coronary artery disease. J. Am. Heart Assoc. 3, e001249. doi: 10.1161/JAHA.114.001249

Jansen, F., Wang, H., Przybilla, D., Franklin, B. S., Dolf, A., Pfeifer, P., et al. (2016). Vascular endothelial microparticles- incorporated microRNAs are altered in patients with diabetes mellitus. Cardiovasc. Diabetol. 15, 49. doi: 10.1186/ s12933-016-0367-8

Jayachandran, M., Miller, V. M., Heit, J. A., and Owen, W. G. (2012). Methodology for isolation, identification and characterization of microvesicles in peripheral blood. J. Immunol. Methods 375, 207-214. doi: 10.1016/j.jim.2011.10.012

Jesel, L., Abbas, M., Toti, F., Cohen, A., Arentz, T., and Morel, O. (2013). Microparticles in atrial fibrillation: a link between cell activation or apoptosis, tissue remodelling and thrombogenicity. Int. J. Cardiol. 168, 660669. doi: 10.1016/j.ijcard.2013.03.031

Ji, Y., Jian, B., Wang, N., Sun, Y., de la Llera Moya, M., Phillips, M. C., et al. (1997). Scavenger receptor BI promotes high density lipoprotein-mediated cellular cholesterol efflux. J. Biol. Chem. 272, 20982-20985. doi: 10.1074/ jbc.272.34.20982
Jian, B., de la Llera-Moya, M., Ji, Y., Wang, N., Phillips, M. C., Swaney, J. B., et al. (1998). Scavenger receptor class B type I as a mediator of cellular cholesterol efflux to lipoproteins and phospholipid acceptors. J. Biol. Chem. 273, 55995606. doi: $10.1074 / j b c .273 .10 .5599$

Jinek, M., and Doudna, J. A. (2009). A three-dimensional view of the molecular machinery of RNA interference. Nat 457, 405-412. doi: 10.1038/nature07755

Johnstone, R. M., Bianchini, A., and Teng, K. (1989). Reticulocyte maturation and exosome release: transferrin receptor containing exosomes shows multiple plasma membrane functions. Blood 74, 1844-1851. doi: 10.1182/ blood.V74.5.1844.1844

Jonas, A. (1991). Lecithin-cholesterol acyltransferase in the metabolism of highdensity lipoproteins. Biochim. Biophys. Acta-Lipids Lipid Metab. 1084, 205220. doi: 10.1016/0005-2760(91)90062-M

Kangas, R., Törmäkangas, T., Fey, V., Pursiheimo, J., Miinalainen, I., Alen, M., et al. (2017). Aging and serum exomiR content in women-effects of estrogenic hormone replacement therapy. Sci. Rep. 7, 42702. doi: 10.1038/srep42702

Khalyfa, A., Zhang, C., Khalyfa, A. A., Foster, G. E., Beaudin, A. E., Andrade, J., et al. (2016). Effect on intermittent hypoxia on plasma exosomalmicro RNA signature and endothelial function in healthy adults. Sleep 39, 2077-2090. doi: 10.5665/sleep.6302

Khare, D., Goldschmidt, N., Bardugo, A., Gur-Wahnon, D., Ben-Dov, I. Z., and Avni, B. (2017). Plasma microRNA profiling: exploring better biomarkers for lymphoma surveillance. PloS ONE 12. doi: 10.1371/journal.pone.0187722

Kim, J., Morley, S., Le, M., Bedoret, D., Umetsu, D. T., Di Vizio, D., et al. (2014). Enhanced shedding of extracellular vesicles from amoeboid prostate cancer cells: potential effects on the tumor microenvironment. Cancer Biol. Ther. 15, 409-418. doi: 10.4161/cbt.27627

Kim, K. M., Abdelmohsen, K., Mustapic, M., Kapogiannis, D., and Gorospe, M. (2017). RNA in extracellular vesicles. Wiley Interdiscip. Rev. RNA 8, e1413. doi: 10.1002/wrna.1413

Kimura, K., Hohjoh, H., Fukuoka, M., Sato, W., Oki, S., Tomi, C., et al. (2018). Circulating exosomes suppress the induction of regulatory $\mathrm{T}$ cells via let-7i in multiple sclerosis. Nat. Commun. 9, 17. doi: 10.1038/s41467-017-02406-2

Kobayashi, T., Tomofuji, T., Machida, T., Yoneda, T., Ekuni, D., Azuma, T., et al. (2017). Expression of salivary miR-203a-3p was related with oral health-related quality of life in healthy volunteers. Int. J. Mol. Sci. 18, 1263. doi: 10.3390/ ijms 18061263

Köberle, V., Pleli, T., Schmithals, C., Alonso, E. A., Haupenthal, J., Bönig, H., et al. (2013). Differential stability of cell-free circulating microRNAs: implications for their utilization as biomarkers. PloS One 8, e75184. doi: 10.1371/ journal.pone.0075184

Koppers-Lalic, D., Hackenberg, M., Bijnsdorp, I. V., van Eijndhoven, M. A., Sadek, P., Sie, D., et al. (2014). Nontemplated nucleotide additions distinguish the small RNA composition in cells from exosomes. Cell Rep. 8, 1649-1658. doi: 10.1016/j.celrep.2014.08.027

Kosaka, N., Iguchi, H., Yoshioka, Y., Takeshita, F., Matsuki, Y., and Ochiya, T. (2010). Secretory mechanisms and intercellular transfer of microRNAs in living cells. J. Biol. Chem. 285, 17442-17452. doi: 10.1074/jbc.M110.107821

Kosaka, N., Iguchi, H., Hagiwara, K., Yoshioka, Y., Takeshita, F., and Ochiya, T. (2013). Neutral sphingomyelinase 2 (nSMase2)-dependent exosomal transfer of angiogenic microRNAs regulate cancer cell metastasis. J. Biol. Chem. 288, 10849-10859. doi: 10.1074/jbc.M112.446831

Krinsky, N. I., Mayne, S. T., and Sies, H. (2004). Carotenoids in health and disease (Boca Raton: CRC Press). doi: 10.1201/9780203026649

Kubiczkova, L., Kryukov, F., Slaby, O., Dementyeva, E., Jarkovsky, J., Nekvindova, J., et al. (2014). Circulating serum microRNAs as novel diagnostic and prognostic biomarkers for multiple myeloma and monoclonal gammopathy of undetermined significance. Haematologica. 99, 511-518. doi: 10.3324/ haematol.2013.093500

Kwak, P. B., and Tomari, Y. (2012). The N domain of Argonaute drives duplex unwinding during RISC assembly. Nat. Struct. Mol. Biol. 19, 145. doi: 10.1038/ nsmb. 2232

Lacroix, R., Judicone, C., Mooberry, M., Boucekine, M., Key, N. S., and DignatGeorge, F. (2013). ISTH SSC Workshop. Standardization of pre-analytical variables in plasma microparticle determination: results of the International Society on Thrombosis and Haemostasis SSC Collaborative workshop. J. Thromb. Haemost. 11, 1190-1193. doi: 10.1111/jth.12207 
Lee, Y. S., Pressman, S., Andress, A. P., Kim, K., White, J. L., Cassidy, J. J., et al. (2009). Silencing by small RNAs is linked to endosomal trafficking. Nat. Cell Biol. 11, 1150. doi: $10.1038 /$ ncb1930

Li, L., Zhu, D., Huang, L., Zhang, J., Bian, Z., Chen, X., et al. (2012). Argonaute 2 complexes selectively protect the circulating microRNAs in cell-secreted microvesicles. PloS One 7, e46957. doi: 10.1371/journal.pone.0046957

Li, Z., Ma, Y. Y., Wang, J., Zeng, X. F., Li, R., Kang, W., et al. (2016). Exosomal microRNA-141 is upregulated in the serum of prostate cancer patients. OncoTargets Ther. 9, 139-148. doi: 10.2147/OTT.S95565

Li, J., Li, B., Ren, C., Chen, Y., Guo, X., Zhou, L., et al. (2017). The clinical significance of circulating GPC1 positive exosomes and its regulative miRNAs in colon cancer patients. Oncotarget 8, 101189-101202. doi: 10.18632/ oncotarget.20516

Lin, H., and Spradling, A. C. (1997). A novel group of pumilio mutations affects the asymmetric division of germline stem cells in the Drosophila ovary. Dev 124, 2463-2476.

Liu, Q., Yu, Z., Yuan, S., Xie, W., Li, C., Hu, Z., et al. (2017a). Circulating exosomal microRNAs as prognostic biomarkers for non-small-cell lung cancer. Oncotarget 8, 13048-13058. doi: 10.18632/oncotarget.14369

Liu, J., Carmell, M. A., Rivas, F. V., Marsden, C. G., Thomson, J. M., Song, J. J., et al. (2004). Argonaute2 is the catalytic engine of mammalian RNAi. Science 305, 1437-1441. doi: 10.1126/science.1102513

Liu, W., Hu, J., Zhou, K., Chen, F., Wang, Z., Liao, B., et al. (2017b). Serum exosomal miR-125b is a novel prognostic marker for hepatocellular carcinoma. OncoTargets Ther. 10, 3843-3851. doi: 10.2147/OTT.S140062

Lou, X. Y., Wu, P. R., and Guo, Y. (2019). Urinary metabolites of polycyclic aromatic hydrocarbons in pregnant women and their association with a biomarker of oxidative stress. Environ. Sci. Pollut. Res. Int. 26, 27281-27290. doi: 10.1007/s11356-019-05855-y

Lv, L. L., Feng, Y., Wu, M., Wang, B., Li, Z. L., Zhong, X., et al. (2019). Exosomal miRNA-19b-3p of tubular epithelial cells promotes M1 macrophage activation in kidney injury. Cell Death Differ. 1, 210-226. doi: 10.1038/ s41418-019-0349-y

Markiewicz, M., Richard, E., Marks, N., and Ludwicka-Bradley, A. (2013). Impact of endothelial microparticles on coagulation, inflammation, and angiogenesis in age-related vascular diseases. J. Aging Res. 2013. doi: 10.1155/2013/734509

Martinez, M. C., and Freyssinet, J. M. (2001). Deciphering the plasma membrane hallmarks of apoptotic cells: phosphatidylserine transverse redistribution and calcium entry. BMC Cell Biol. 2, 20. doi: 10.1186/1471-2121-2-20

Mathivanan, S., Ji, H., and Simpson, R. J. (2010). Exosomes: extracellular organelles important in intercellular communication. J. Proteomics 73, 19071920. doi: $10.1016 /$ j.jprot.2010.06.006

Maugeri, N., Capobianco, A., Rovere-Querini, P., Ramirez, G. A., Tombetti, E., Della Valle, P., et al. (2018). Platelet microparticles sustain autophagyassociated activation of neutrophils in systemic sclerosis. Sci. Translat. Med. 10, eaao3089. doi: 10.1126/scitranslmed.aao3089

Mause, S. F., von Hundelshausen, P., Zernecke, A., Koenen, R. R., and Weber, C. (2010). Platelet microparticles: a transcellular delivery system for RANTES promoting monocyte recruitment on endothelium. Arterioscler. Thromb. Vasc. Biol. 25, 1512-1518. doi: 10.1161/01.ATV.0000170133.43608.37

McAtee, C. O., Booth, C., Elowsky, C., Zhao, L., Payne, J., Fangman, T., et al. (2019). Prostate tumor cell exosomes containing hyaluronidase Hyal1 stimulate prostate stromal cell motility by engagement of FAK-mediated integrin signaling. Matrix Biol. 78, 165-179. doi: 10.1016/j.matbio.2018.05.002

McConnell, R. E., Higginbotham, J. N., Shifrin, D. A., Tabb, D. L., Coffey, R. J., and Tyska, M. J. (2009). The enterocyte microvillus is a vesicle-generating organelle. J. Cell Biol. 185, 1285-1298. doi: 10.1083/jcb.200902147

Meister, G., Landthaler, M., Patkaniowska, A., Dorsett, Y., Teng, G., and Tuschl, T. (2004). Human Argonaute2 mediates RNA cleavage targeted by miRNAs and siRNAs. Mol. Cell 15, 185-197. doi: 10.1016/j.molcel.2004.07.007

Melman, Y. F., Shah, R., Danielson, K., Xiao, J., Simonson, B., Barth, A., et al. (2015). Circulating MicroRNA-30d is associated with response to cardiac resynchronization therapy in heart failure and regulates cardiomyocyte apoptosis: a translational pilot study. Circulation 131, 2202-2216. doi: 10.1161/CIRCULATIONAHA.114.013220

Meng, X., Müller, V., Milde-Langosch, K., Trillsch, F., Pantel, K., and Schwarzenbach, H. (2016). Diagnostic and prognostic relevance of circulating exosomal miR-373, miR- 200a, miR-200b and miR-200c in patients with epithelial ovarian cancer. Oncotarget 7, 16923-16935. doi: 10.18632 /oncotarget.7850

Mevorach, D., Mascarenhas, J. O., Gershov, D., and Elkon, K. B. (1998). Complement-dependent clearance of apoptotic cells by human macrophages. J. Exp. Med. 188, 2313-2320. doi: 10.1084/jem.188.12.2313

Mo, M. H., Chen, L., Fu, Y., Wang, W., and Fu, S. W. (2012). Cell-free circulating miRNA biomarkers in cancer. J. Cancer 3, 432-448. doi: 10.7150/jca.4919

Moen, A., Jacobsen, D., Phuyal, S., Legfeldt, A., Haugen, F., Røe, C., et al. (2017). MicroRNA-223 demonstrated experimentally in exosome-like vesicles is associated with decreased risk of persistent pain after lumbar disc herniation. J. Transl. Med. 15, 89. doi: 10.1186/s12967-017-1194-8

Momen-Heravi, F., Saha, B., Kodys, K., Catalano, D., Satishchandran, A., and Szabo, ,. G. (2015). Increased number of circulating exosomes and their microRNA cargos are potential novel biomarkers in alcoholic hepatitis. $J$. Transl. Med. 13, 261. doi: 10.1186/s12967-015-0623-9

Morel, O., Jesel, L., Freyssinet, J. M., and Toti, F. (2011). Cellular mechanisms underlying the formation of circulating microparticles. Arterioscler. Thromb. Vasc. Biol. 31, 15-26. doi: 10.1161/ATVBAHA.109.200956

Morelli, A. E., Larregina, A. T., Shufesky, W. J., Sullivan, M. L., Stolz, D. B., Papworth, G. D., et al. (2004). Endocytosis, intracellular sorting, and processing of exosomes by dendritic cells. Blood 104, 3257-3266. doi: 10.1182/blood-2004-03-0824

Muralidharan-Chari, V., Clancy, J., Plou, C., Romao, M., Chavrier, P., Raposo, G., et al. (2009). ARF6-regulated shedding of tumor cell-derived plasma membrane microvesicles. Curr. Biol. 19, 1875-1885. doi: 10.1016/ j.cub.2009.09.059

Murray, D. D., Suzuki, K., Law, M., Trebicka, J., Nordwall, J. N., Johnson, M., et al. (2017). Circulating miR-122 and miR-200a as biomarkers for fatal liver disease in ART-treated, HIV-1-infected individuals. Sci. Rep. 7, 10934. doi: 10.1038/ s41598-017-11405-8

Nabhan, J. F., Hu, R., Oh, R. S., Cohen, S. N., and Lu, Q. (2012). Formation and release of arrestin domain-containing protein 1-mediated microvesicles (ARMMs) at plasma membrane by recruitment of TSG101 protein. Proc. Natl. Acad. Sci. U.S.A. 109, 4146-4151. doi: 10.1073/pnas.1200448109

Niculescu, L. S., Simionescu, N., Sanda, G. M., Carnuta, M. G., Stancu, C. S., Popescu, A. C., et al. (2015). MiR-486 and miR-92a identified in circulating HDL discriminate between stable and vulnerable coronary artery disease patients. PloS One 10, e0140958. doi: 10.1371/journal.pone.0140958

O'Brien, J., Hayder, H., Zayed, Y., and Peng, C. (2018). Overview of microrna biogenesis, mechanisms of actions, and circulation. Front. Endocrinol. 9, 402. doi: 10.3389/fendo.2018.00402

Ogata-Kawata, H., Izumiya, M., Kurioka, D., Honma, Y., Yamada, Y., Furuta, K., et al. (2014). Circulating exosomal microRNAs as biomarkers of colon cancer. PloS One 9, e92921. doi: 10.1371/journal.pone.0092921

Ostenfeld, M. S., Jensen, S. G., Jeppesen, D. K., Christensen, L. L., Thorsen, S. B., Stenvang, J., et al. (2016). miRNA profiling of circulating EpCAM+ extracellular vesicles: promising biomarkers of colorectal cancer. J. Extracell Vesicles 5, 31488. doi: 10.3402/jev.v5.31488

Ostrowski, M., Carmo, N. B., Krumeich, S., Fanget, I., Raposo, G., Savina, A., et al. (2010). Rab27a and Rab27b control different steps of the exosome secretion pathway. Nat. Cell Biol. 12, 19. doi: 10.1038/ncb2000

Pan, B. T., and Johnstone, R. M. (1983). Fate of the transferrin receptor during maturation of sheep reticulocytes in vitro: selective externalization of the receptor. Cell 33, 967-978. doi: 10.1016/0092-8674(83)90040-5

Parker, J. S., Roe, S. M., and Barford, D. (2005). Structural insights into mRNA recognition from a PIWI domain-siRNA guide complex. Nat 434, 663. doi: 10.1038/nature03462

Perge, P., Butz, H., Pezzani, R., Bancos, I., Nagy, Z., Pálóczi, K., et al. (2017). Evaluation and diagnostic potential of circulating extracellular vesicleassociated microRNAs in adrenocortical tumors. Sci. Rep. 7, 5474. doi: 10.1038/s41598-017-05777-0

Pieper, I. L., Radley, G., Christen, A., Ali, S., Bodger, O., and Thornton, C. A. (2018). Ovine leukocyte microparticles generated by the centrimag ventricular assist device in vitro. Artif. Orgs. 42, E78-E89. doi: 10.1111/aor.13068

Pirola, C. J., Gianotti, T. F., Castaño, G. O., Mallardi, P., San Martino, J., Ledesma, M. M. G. L., et al. (2015). Circulating microRNA signature in non-alcoholic fatty liver disease: from serum, non-coding RNAs to liver histology and disease pathogenesis. Gut 64, 800-812. doi: 10.1136/gutjnl-2014-306996 
Rabinowits, G., Bowden, M., Flores, L. M., Verselis, S., Vergara, V., Jo, V. Y., et al. (2017). Comparative analysis of microRNA expression among benign and malignant tongue tissue and plasma of patients with tongue cancer. Front. Oncol. 7, 191. doi: 10.3389/fonc.2017.00191

Ragusa, M., Barbagallo, C., Statello, L., Caltabiano, R., Russo, A., Puzzo, L., et al. (2015). miRNA profiling in vitreous humor, vitreal exosomes and serum from uveal melanoma patients: pathological and diagnostic implications. Cancer Biol. Ther. 16, 1387-1396. doi: 10.1080/15384047.2015. 1046021

Ramachandran, S., Lowenthal, A., Ritner, C., Lowenthal, S., and Bernstein, H. S. (2017). Plasma microvesicle analysis identifies microRNA 129-5p as a biomarker of heart failure in univentricular heart disease. PloS One 12, e0183624. doi: 10.1371/journal.pone.0183624

Ramezani, A., Devaney, J. M., Cohen, S., Wing, M. R., Scott, R., Knoblach, S., et al. (2015). Circulating and urinary micro RNA profile in focal segmental glomerulosclerosis: a pilot study. Eur. J. Clin. Invest. 45, 394-404. doi: $10.1111 /$ eci. 12420

Rani, A., O'Shea, A., Ianov, L., Cohen, R. A., Woods, A. J., and Foster, T. C. (2017). miRNA in circulating microvesicles as biomarkers for age-related cognitive decline. Front. Aging Neurosci. 9, 323. doi: 10.3389/fnagi.2017.00323

Redis, R. S., Calin, S., Yang, Y., You, M. J., and Calin, G. A. (2012). Cell-to-cell miRNA transfer: from body homeostasis to therapy. Pharmacol. Ther. 136, 169-174. doi: 10.1016/j.pharmthera.2012.08.003

Reithmair, M., Buschmann, D., Märte, M., Kirchner, B., Hagl, D., Kaufmann, I., et al. (2017). Cellular and extracellular mi RNA s are blood-compartmentspecific diagnostic targets in sepsis. J. Cell Mol. Med. 21, 2403-2411. doi: $10.1111 / \mathrm{jcmm} .13162$

Rilla, K., Pasonen-Seppänen, S., Deen, A. J., Koistinen, V. V., Wojciechowski, S., Oikari, S., et al. (2013). Hyaluronan production enhances shedding of plasma membrane-derived microvesicles. Exp. Cell Res. 319, 2006-2018. doi: 10.1016/ j.yexcr.2013.05.021

Sattler, W., Levak-Frank, S., Radner, H., Kostner, G. M., and Zechner, R. (1996). Muscle-specific overexpression of lipoprotein lipase in transgenic mice results in increased alpha-tocopherol levels in skeletal muscle. Biochem. J. 318, 15. doi: 10.1042/bj3180015

Savill, J., Hogg, N., Ren, Y., and Haslett, C. (1992). Thrombospondin cooperates with $\mathrm{CD} 36$ and the vitronectin receptor in macrophage recognition of neutrophils undergoing apoptosis. J. Clin. Invest. 90, 1513-1522. doi: 10.1172/JCI116019

Savill, J. (1997). Recognition and phagocytosis of cells undergoing apoptosis. $\mathrm{Br}$. Med. Bull. 53, 491-508. doi: 10.1093/oxfordjournals.bmb.a011626

Schlienger, S., Campbell, S., and Claing, A. (2014). ARF1 regulates the Rho/MLC pathway to control EGF-dependent breast cancer cell invasion. Mol. Biol. Cell 25, 17-29. doi: 10.1091/mbc.e13-06-0335

Sedgwick, A. E., Clancy, J. W., Balmert, M. O., and D'Souza-Schorey, C. (2015). Extracellular microvesicles and invadopodia mediate non-overlapping modes of tumor cell invasion. Sci. Rep. 5, 14748. doi: 10.1038/srep14748

Seow, P., Narayanan, V., Romelean, R. J., Wong, J. H. D., Win, M. T., Chandran, H., et al. (2019). Lipid fraction derived from MRI in-and opposed-phase sequence as a novel biomarker for predicting survival outcome of glioma. Acad. Radiol. doi: 10.1016/j.acra.2019.04.015

Shah, M. S., DeSantis, T. Z., Weinmaier, T., McMurdie, P. J., Cope, J. L., Altrichter, A., et al. (2018). Leveraging sequence-based faecal microbial community survey data to identify a composite biomarker for colorectal cancer. Gut 67, 882-891. doi: 10.1136/gutjnl-2016-313189

Simons, M., and Raposo, G. (2009). Exosomes - vesicular carriers for intercellular communication. Curr. Opin. Cell Biol. 21, 575-581. doi: 10.1016/ j.ceb.2009.03.007

Smalley, D. M., Sheman, N. E., Nelson, K., and Theodorescu, D. (2008). Isolation and identification of potential urinary microparticle biomarkers of bladder cancer. J. Proteome Res. 7, 2088- 2096. doi: 10.1021/pr700775x

Sohn, W., Kim, J., Kang, S. H., Yang, S. R., Cho, J. Y., Cho, H. C., et al. (2015). Serum exosomal microRNAs as novel biomarkers for hepatocellular carcinoma. Exp. Mol. Med. 47, e184. doi: 10.1038/emm.2015.68

Stachowiak, J. C., Schmid, E. M., Ryan, C. J., Ann, H. S., Sasaki, D. Y., Sherman, M. B., et al. (2012). Membrane bending by protein-protein crowding. Nat. Cell Biol. 14, 944. doi: $10.1038 /$ ncb2561
Stachowiak, J. C., Brodsky, F. M., and Miller, E. A. (2013). A cost-benefit analysis of the physical mechanisms of membrane curvature. Nat. Cell Biol. 15, 1019. doi: $10.1038 / \mathrm{ncb} 2832$

Sugimachi, K., Matsumura, T., Hirata, H., Uchi, R., Ueda, M., Ueo, H., et al. (2015). Identification of a bona fide microRNA biomarker in serum exosomes that predicts hepatocellular carcinoma recurrence after liver transplantation. Br. J. Cancer 112, 532-538. doi: 10.1038/bjc.2014.621

Tabet, F., Torres, L. F. C., Ong, K. L., Shrestha, S., Choteau, S. A., Barter, P. J., et al. (2016). High-density lipoprotein-associated miR-223 is altered after dietinduced weight loss in overweight and obese males. PloS One 11, e0151061. doi: 10.1371/journal.pone.0151061

Takizawa, F., Tsuji, S., and Nagasawa, S. (1996). Enhancement of macrophage phagocytosis upon iC3b deposition on apoptotic cells. FEBS Lett. 397, 269-272. doi: 10.1016/S0014-5793(96)01197-0

Tall, A. R. (1993). Plasma cholesteryl ester transfer protein. J. Lipid Res. 34, 12551274.

Teng, Y., Ren, Y., Hu, X., Mu, J., Samykutty, A., Zhuang, X., et al. (2017). MVPmediated exosomal sorting of miR-193a promotes colon cancer progression. Nat. Commun. 8, 14448. doi: 10.1038/ncomms14448

Teo, Y. V., Capri, M., Morsiani, C., Pizza, G., Faria, A. M. C., Franceschi, C., et al. (2019). Cell-free DNA as a biomarker of aging. Aging Cell 18, e12890. doi: 10.1111/acel.12890

Tikkanen, M. J., Vihma, V., Jauhiainen, M., Höckerstedt, A., Helisten, H., and Kaamanen, M. (2002). Lipoprotein-associated estrogens. Cardiovasc. Res. 56, 184-188. doi: 10.1016/S0008-6363(02)00535-7

Trajkovic, K., Hsu, C., Chiantia, S., Rajendran, L., Wenzel, D., Wieland, F., et al. (2008). Ceramide triggers budding of exosome vesicles into multivesicular endosomes. Science 319, 1244-1247. doi: 10.1126/science.1153124

Tricarico, C., Clancy, J., and D'Souza-Schorey, C. (2017). Biology and biogenesis of shed microvesicles. Small GTPases 8, 220-232. doi: 10.1080/ 21541248.2016.1215283

Turchinovich, A., Weiz, L., Langheinz, A., and Burwinkel, B. (2011). Characterization of extracellular circulating microRNA. Nucleic Acids Res. 39, 7223-7233. doi: 10.1093/nar/gkr254

Uotani, K., Fujiwara, T., Yoshida, A., Iwata, S., Morita, T., Kiyono, M., et al. (2017). Circulating MicroRNA-92b-3p as anovel biomarker for monitoring of synovial sarcoma. Sci. Rep. 7, 14634. doi: 10.1038/s41598-017-12660-5

Uratani, R., Toiyama, Y., Kitajima, T., Kawamura, M., Hiro, J., Kobayashi, M., et al. (2016). Diagnostic potential of cell-free and exosomal microRNAs in the identification of patients with high-risk colorectal adenomas. PloS One 11, e0160722. doi: 10.1371/journal.pone.0160722

Vaisar, T., Shao, B., Green, P. S., Oda, M. N., Oram, J. F., and Heinecke, J. W. (2007). Myeloperoxidase and inflammatory proteins: pathways for generating dysfunctional high-density lipoprotein in humans. Curr. Atheroscler. Rep. 9, 417-424. doi: 10.1007/s11883-007-0054-Z

van Eijndhoven, M. A., Zijlstra, J. M., Groenewegen, N. J., Drees, E. E., van Niele, S., Baglio, S. R., et al. (2016). Plasma vesicle miRNAs for therapy response monitoring in Hodgkinlymphoma patients. JCI Insight 1, e89631. doi: 10.1172/jci.insight. 89631

Vedhachalam, C., Duong, P. T., Nickel, M., Nguyen, D., Dhanasekaran, P., Saito, H., et al. (2007). Mechanism of ATP-binding cassette transporter A1mediated cellular lipid efflux to apolipoprotein AI and formation of high density lipoprotein particles. J. Biol. Chem. 282, 25123-25130. doi: 10.1074/ jbc.M704590200

Vickers, K. C., and Remaley, A. T. (2013). Functional diversity of HDL cargo. J. Lipid Res. 55, 4-12. doi: 10.1194/jlr.R035964

Vickers, K. C., Palmisano, B. T., Shoucri, B. M., Shamburek, R. D., and Remaley, A. T. (2011). MicroRNAs are transported in plasma and delivered to recipient cells by high-density lipoproteins. Nat. Cell Biol. 13, 423-433. doi: $10.1038 / \mathrm{ncb} 2210$

Villarroya-Beltri, C., Gutiérrez-Vázquez, C., Sánchez-Cabo, F., PérezHernández, D., Vázquez, J., Martin-Cofreces, N., et al. (2013). Sumoylated hnRNPA2B1 controls the sorting of miRNAs into exosomes through binding to specific motifs. Nat. Commun. 4, 2980. doi: 10.1038/ncomms3980

Wang, G., Chen, H. W., Oktay, Y., Zhang, J., Allen, E. L., Smith, G. M., et al. (2010). PNPASE regulates RNA import into mitochondria. Cell 142, 456-467. doi: $10.1016 /$ j.cell.2010.06.035 
Wang, T., Gilkes, D. M., Takano, N., Xiang, L., Luo, W., Bishop, C. J., et al. (2014). Hypoxia-inducible factors and RAB22A mediate formation of microvesicles that stimulate breast cancer invasion and metastasis. Proc. Natl. Acad. Sci. 111, E3234-E3242. doi: 10.1073/pnas.1410041111

Wang, J., Yan, F., Zhao, Q., Zhan, F., Wang, R., Wang, L., et al. (2017). Circulating exosomal miR-125a-3p as a novel biomarker for early-stage colon cancer. Sci. Rep. 7, 4150. doi: 10.1038/s41598-017-04386-1

Wang, X., Shen, H., He, Q., Tian, W., Xia, A., and Lu, X. J. (2019). Exosomes derived from exhausted CD8+ T cells impaired the anticancer function of normal CD8+ T cells. J. Med. Genet. 56, 29-31. doi: 10.1136/jmedgenet-2018-105439

Weilner, S., Schraml, E., Wieser, M., Messner, P., Schneider, K., Wassermann, K., et al. (2016). Secreted microvesicular miR-31 inhibits osteogenic differentiation of mesenchymal stem cells. Aging Cell 15, 744-754. doi: 10.1111/acel.12484

Xie, G., Yang, H., Peng, X., Lin, L., Wang, J., Lin, K., et al. (2018). Mast cell exosomes can suppress allergic reactions by binding to IgE. J. Allergy Clin. Immunol. 141, 788-791. doi: 10.1016/j.jaci.2017.07.040

Xu, Y. W., Chen, H., Wu, Z. Y., Hong, C. Q., Chu, L. Y., Yang, S. H., et al. (2019). IGFBP-1 as a serum protein biomarker for early detection of gastrointestinal cancer.

Yan, S., Han, B., Gao, S., Wang, X., Wang, Z., Wang, F., et al. (2017). Exosomeencapsulated microRNAs as circulating biomarkers for colorectal cancer. Oncotarget 8, 60149-60158. doi: 10.18632/oncotarget.18557

Ye, S. B., Li, Z. L., Luo, D. H., Huang, B. J., Chen, Y. S., Zhang, X. S., et al. (2014). Tumor-derived exosomes promote tumor progression and T-cell dysfunction through the regulation of enriched exosomal microRNAs in human nasopharyngeal carcinoma. Oncotarget 5, 5439-5452. doi: 10.18632/ oncotarget.2118

Yigit, E., Batista, P. J., Bei, Y., Pang, K. M., Chen, C. C., Tolia, N. H., et al. (2006). Analysis of the C. elegans Argonaute family reveals that distinct Argonautes act sequentially during RNAi. Cell 127, 747-757. doi: 10.1016/j.cell.2006.09.033
Yokoi, A., Yoshioka, Y., Hirakawa, A., Yamamoto, Y., Ishikawa, M., Ikeda, S. I., et al. (2017). A combination of circulatingmiRNAs for the early detection of ovarian cancer. Oncotarget 8, 89811-89823. doi: 10.18632/oncotarget.20688

Yu, X., Harris, S. L., and Levine, A. J. (2006). The regulation of exosome secretion: a novel function of the p53 protein. Cancer Res. 66, 4795-4801. doi: 10.1158/ 0008-5472.CAN-05-4579

Yuan, T., Huang, X., Woodcock, M., Du, M., Dittmar, R., Wang, Y., et al. (2016). Plasma extracellular RNA profiles in healthy and cancer patients. Sci. Rep. 6, 19413. doi: 10.1038/srep19413

Yuan, Y., Muyesai, N., and Abdeyrim, A. (2018). Comparison of erythrocyte microparticle levels between acute coronary syndrome and stable angina pectoris patients. Int. J. Clin. Exp. Med. 11, 9528-9535.

Zhang, J., Li, S., Li, L., Li, M., Guo, C., Yao, J., et al. (2015). Exosome and exosomal microRNA: trafficking, sorting, and function. Genomics Proteomics Bioinf. 13, 17-24. doi: 10.1016/j.gpb.2015.02.001

Zhang, Y., Cheng, J., Chen, F., Wu, C., Zhang, J., Ren, X., et al. (2017). Circulating endothelial microparticles and miR-92a in acute myocardial infarction. Biosci. Rep. 37, BSR20170047. doi: 10.1042/BSR20170047

Conflict of Interest: The authors declare that the research was conducted in the absence of any commercial or financial relationships that could be construed as a potential conflict of interest.

Copyright (c) 2020 Nik Mohamed Kamal and Shahidan. This is an open-access article distributed under the terms of the Creative Commons Attribution License (CC BY). The use, distribution or reproduction in other forums is permitted, provided the original author(s) and the copyright owner(s) are credited and that the original publication in this journal is cited, in accordance with accepted academic practice. No use, distribution or reproduction is permitted which does not comply with these terms. 